\title{
Increasing the Clinical Potential and Applications of Anti-HIV Antibodies
}

\author{
Casey K. Hua ${ }^{1}$ and Margaret E. Ackerman ${ }^{1,2 *}$ \\ ${ }^{1}$ Department of Microbiology and Immunology, Geisel School of Medicine, Lebanon, NH, United States, \\ ${ }^{2}$ Thayer School of Engineering, Dartmouth College, Hanover, NH, United States
}

OPEN ACCESS

Edited by:

Gabriella Scarlatti,

San Raffaele Hospital

(IRCCS), Italy

Reviewed by:

Penny Moore,

WITS University,

South Africa

Stephen Kent,

University of Melbourne,

Australia

*Correspondence:

Margaret E. Ackerman

margaret.e.ackerman@

dartmouth.edu

Specialty section:

This article was submitted to HIV and AIDS,

a section of the journal

Frontiers in Immunology

Received: 29 August 2017 Accepted: 13 November 2017 Published: 28 November 2017

Citation:

Hua CK and Ackerman ME (2017) Increasing the Clinical Potential and Applications of Anti-HIV

Antibodies.

Front. Immunol. 8:1655. doi: 10.3389/fimmu.2017.01655
Preclinical and early human clinical studies of broadly neutralizing antibodies (bNAbs) to prevent and treat HIV infection support the clinical utility and potential of bNAbs for prevention, postexposure prophylaxis, and treatment of acute and chronic infection. Observed and potential limitations of bNAbs from these recent studies include the selection of resistant viral populations, immunogenicity resulting in the development of antidrug $(\mathrm{Ab})$ responses, and the potentially toxic elimination of reservoir cells in regeneration-limited tissues. Here, we review opportunities to improve the clinical utility of HIV Abs to address these challenges and further accomplish functional targets for anti-HIV $\mathrm{Ab}$ therapy at various stages of exposure/infection. Before exposure, bNAbs' ability to serve as prophylaxis by neutralization may be improved by increasing serum half-life to necessitate less frequent administration, delivering genes for durable in vivo expression, and targeting bNAbs to sites of exposure. After exposure and/or in the setting of acute infection, bNAb use to prevent/reduce viral reservoir establishment and spread may be enhanced by increasing the potency with which autologous adaptive immune responses are stimulated, clearing acutely infected cells, and preventing cell-cell transmission of virus. In the setting of chronic infection, bNAbs may better mediate viral remission or "cure" in combination with antiretroviral therapy and/or latency reversing agents, by targeting additional markers of tissue reservoirs or infected cell types, or by serving as targeting moieties in engineered cell therapy. While the clinical use of HIV Abs has never been closer, remaining studies to precisely define, model, and understand the complex roles and dynamics of HIV Abs and viral evolution in the context of the human immune system and anatomical compartmentalization will be critical to both optimize their clinical use in combination with existing agents and define further strategies with which to enhance their clinical safety and efficacy.

Keywords: HIV antibodies, virus neutralization, passive immunotherapy, antibody prophylaxis, antibody engineering

\section{INTRODUCTION}

Antibody (Ab)-based therapies have a robust history of therapeutic utility in the setting of infectious diseases, first serving as serum therapy in the 1800 s to treat diphtheria and most recently, as monoclonal antibody $(\mathrm{mAb})$ preparations developed to combat emergent outbreaks such as Ebola. Endogenous antibodies raised within the context of HIV infection have similarly demonstrated antiviral activity (1), but typically arise too late in the natural history of infection to prevent disease progression (2). Within infected individuals, viral populations consistently outpace host immune responses in a coevolutionary race to gain functionally favorable mutations contributing to immune evasion or viral 


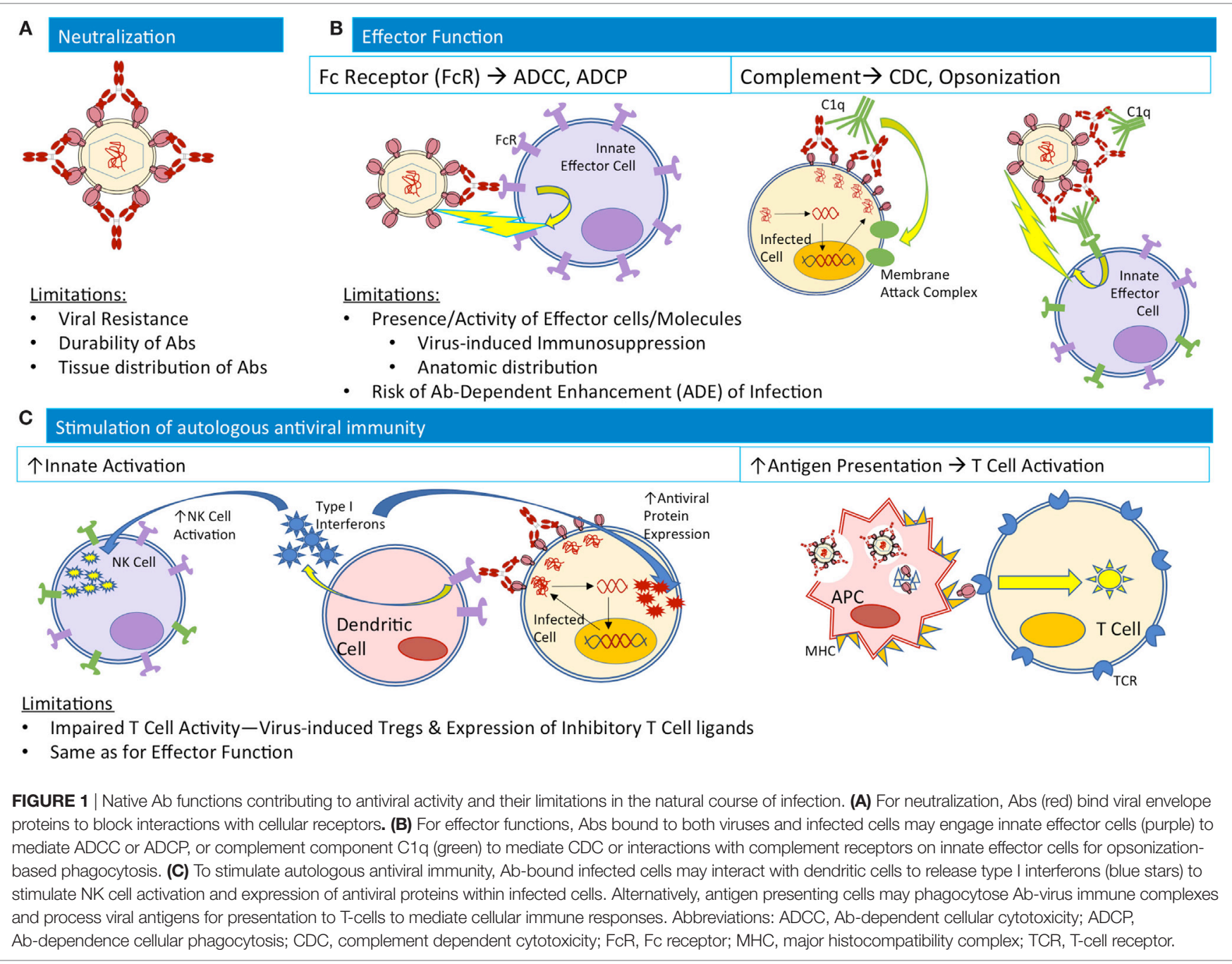

neutralization/suppression, respectively. However, heterologous administration of particularly potent and broad antibodies prior to exposure or to acutely infected individuals has demonstrated therapeutic utility in humanized mice (3-7), macaques (8-13), and humans (14-19).

Several reviews have described the activity and potential of broadly neutralizing antibodies (bNAbs) for HIV prevention and therapy (20-27). Building upon a recent comprehensive review of engineering opportunities to extend the functional capacity and antiviral activity of bNAbs (28), this review incorporates findings from more recently published macaque and human bNAb clinical trials to explore both observed and potential challenges to successful bNAb implementation at various stages of exposure/disease to prevent infection, minimize viral spread, suppress viral growth, and eliminate viral populations.

\section{Promise/Potential: bNAbs in Human Clinical and Macaque Preclinical Trials}

The abundance of studies supporting the antiviral activity and potential of bNAbs to mediate protection from and control of HIV infection in animal models have renewed hope and interest in bNAbs for clinical use. Antibodies can exert antiviral activity through a combination of (1) virus neutralization, preventing initial infection, and viral spread, (2) Fc-mediated effector functions, contributing to the clearance of infected cells, and (3) enhancement of endogenous host antiviral immune responses (Figure 1). In the last 2 years alone, promising human clinical studies to investigate therapeutic benefit in postinfection settings (14-19) and additional preclinical studies to investigate protective efficacy in preexposure/infection settings $(29,30)$ have clarified the mechanisms of action and efficacy of bNAb administration.

Human clinical studies of VRC01 $(14,17,31), 3 \mathrm{BNC} 117(15,18$, 19,32), and 10-1074 (16) have demonstrated the antiviral activity of bNAbs, offering therapeutic utility in both acute and chronic infection settings. Beyond safety and tolerability, all three bNAbs reduced viral load (15-17) during administration and two, VRC01 and 3BNC117, successfully delayed viral rebound upon discontinuation of antiretroviral therapy $(\operatorname{ART})(14,18)$. Treatment dosing regimens remain to be optimized and may differ among Abs, dependent upon both the usual considerations of individual $\mathrm{mAb}$ pharmacokinetic and pharmacodynamic properties, but also each mAb's HIV-specific pharmacodynamic 
properties, such as the slope and completeness of neutralization (33), susceptibility to viral evasion, and propensity to mediate viral (or antigen) trafficking/processing/presentation. In addition, characteristics of individual subjects, such as viral load, diversity, and sensitivity to select bNAb(s) at time of treatment may be considered for more individualized regimens.

Concurrently with direct antiviral activity, treatment with 3BNC117 stimulated and enhanced endogenous antiviral immune responses: in 14/15 viremic individuals treated with $3 \mathrm{BNC} 117$, sera from week 24, well after serum levels of 3BNC117 had dropped below detection limits, demonstrated increased breadth and/or potency against a pseudovirus panel as compared to week 0 (19). Interestingly, the increase in neutralization capacity of week 24 sera from ART-treated individuals receiving 3BNC117 was less pronounced than in untreated individuals receiving $3 \mathrm{BNC} 117$, suggesting that viral replication and activity contributes to the development of heterologous neutralization (19). Previous studies have also demonstrated the enhancement $(13,34,35)$ and importance (36) of autologous humoral and $\mathrm{T}$-cell responses in response to bNAb therapy in macaque models of SHIV [reviewed in Ref. (37)].

The use of HIV Abs in preclinical animal models have similarly demonstrated the potential of $\mathrm{mAbs}$ to provide pre- or postexposure prophylaxis, similarly to the early use of immunoglobulins to protect against infection by RSV and Hepatitis A [reviewed in Ref. (38)]. Protection against SHIV acquisition has been demonstrated for multiple bNAbs $(9-11,39-41)$ with protection dependent upon SHIV strain, bNAb dosage, and bNAb serum concentrations at time of challenge. In models of high-dose SHIV challenge, treatment with $\geq 5 \mathrm{mg} / \mathrm{kg} 3 \mathrm{BNC117}$ or $10-1074$ successfully blocked SHIV acquisition after a single intrarectal challenge of 1,000 times the $50 \%$ tissue culture infectious dose (TCID50), or approximately three times the half-maximal animal infectious dose (42). In a larger study ( 60 challenged animals vs. 4 ), the same group determined that serum titers of bNAbs as low as 1:100 were sufficient to prevent SHIV acquisition in $\sim 50 \%$ of macaques receiving a single intrarectal challenge at 1,000 TCID50 (8). More recently, the same three bNAbs studied in human clinical trials, VRC01, 3BNC117, and 10-1074, have been tested in preclinical macaque models of repeated low-dose SHIV exposure with impressive results (29). A single infusion of 3BNC117 successfully prevented virus acquisition in models of repeated low-dose intrarectal challenges for up to 23 weekly intrarectal challenges at 10 times the TCID50, whereas control animals acquired infection after two to six challenges. Across the three bNAbs evaluated, the length of protection correlated with Ab potency and half-life. Similarly, in humanized mouse models of HIV acquisition, passive transfer of the bNAb PGT126 demonstrated sterilizing protection against multiple vaginal HIV challenges (30).

\section{Role of Non-Neutralizing Abs (nnAbs)}

As opposed to neutralizing Abs which bind epitopes on functional trimeric Env to prevent cell receptor engagement, nnAbs bind epitopes exposed in non-infective conformations adopted by the unstable Env antigen, such as open Envelope trimers, gp140 monomers, and dissociated gp41 stumps (due to instability or induced by binding to cell receptors). nnAb responses have demonstrated protection through Fc-mediated effector functions and by exerting additional selective pressure and evolutionary constraints upon remaining viruses in humanized mice $(43,44)$. In a recent study, Horwitz et al. demonstrated the capacity of nnAbs to modulate the course of HIV infection in humanized mice via Fc-mediated effector functions in two nnAb cases: (1) using anti-HA Abs in humanized mice challenged with a newly developed recombinant indicator HIV strain containing an HA-tag-, (HIVivoHA) or HIVivoHA-infected cells and (2) using a patient-derived nnAb 246D (45) targeting a linear gp41 epitope in humanized mice challenged with HIV-1 $1_{\mathrm{YU} 2}$ virus or HIV-1 $1_{\text {YU2 }}$-infected cells (44). In both cases, passive transfer of nnAbs mediated modest protection from viral challenge, reduced viral load in established infection, cleared virus-infected cells, and exerted selective pressure for escape mutations that ultimately deleted or concealed the targeted epitope, all in an Fc-dependent manner that was diminished or absent in passive transfer of the same nnAbs modified with mutations that abrogated binding to activating Fc-receptors (44). Older studies in macaques have suggested that nnAbs may decrease the number of transmitted/ founder variants and the viral load in acute viremia, but ultimately did not protect from infection (46-48). Thus while the efficacy of nAbs has been linked to Fc-dependent mechanisms (40) the sufficiency of these antibody activities to drive protection from infection among nnAbs has not been established in NHP. Similarly, the protective capacity of non-neutralizing HIV Abs in humans has been suggested by mother-to-child-transmission studies [reviewed in Ref. (49)] and by the association of V1/V2 nnAbs with protection in the RV144 HIV-1 vaccine trial $(50,51)$, but remains to be demonstrated.

\section{Therapeutic Applications and Goals by Stage of Infection}

Based on the established roles of mAbs in various infectious diseases, autologous Abs in the natural history of HIV infection, and HIV Abs in clinical and preclinical trials, anti-HIV mAbs find multiple indications for clinical use with therapeutic goals defined by the stage of HIV exposure and disease (Figure 2). Before viral establishment, mAbs could be used either prior to exposure to prevent viral acquisition or postexposure to prevent or limit viral establishment. After viral acquisition in chronic infection settings, therapeutic goals extend to include viral suppression to stabilize and prevent progression of disease, and viral eradication to cure patients entirely of infection. This review investigates the current limitations of and engineering strategies with which to improve the utility of bNAbs at each stage of infection/disease to (1) prevent infection, (2) limit viral establishment/spread, and (3) treat chronic infection via suppression of viral growth and reduction/elimination of viral reservoirs (summarized in Table 1).

\section{ENHANCING PREEXPOSURE PROPHYLACTIC POTENTIAL: PREVENTING VIRAL INFECTION}

Development of durable protection against HIV has remained a challenge due to the great diversity of HIV species and their 


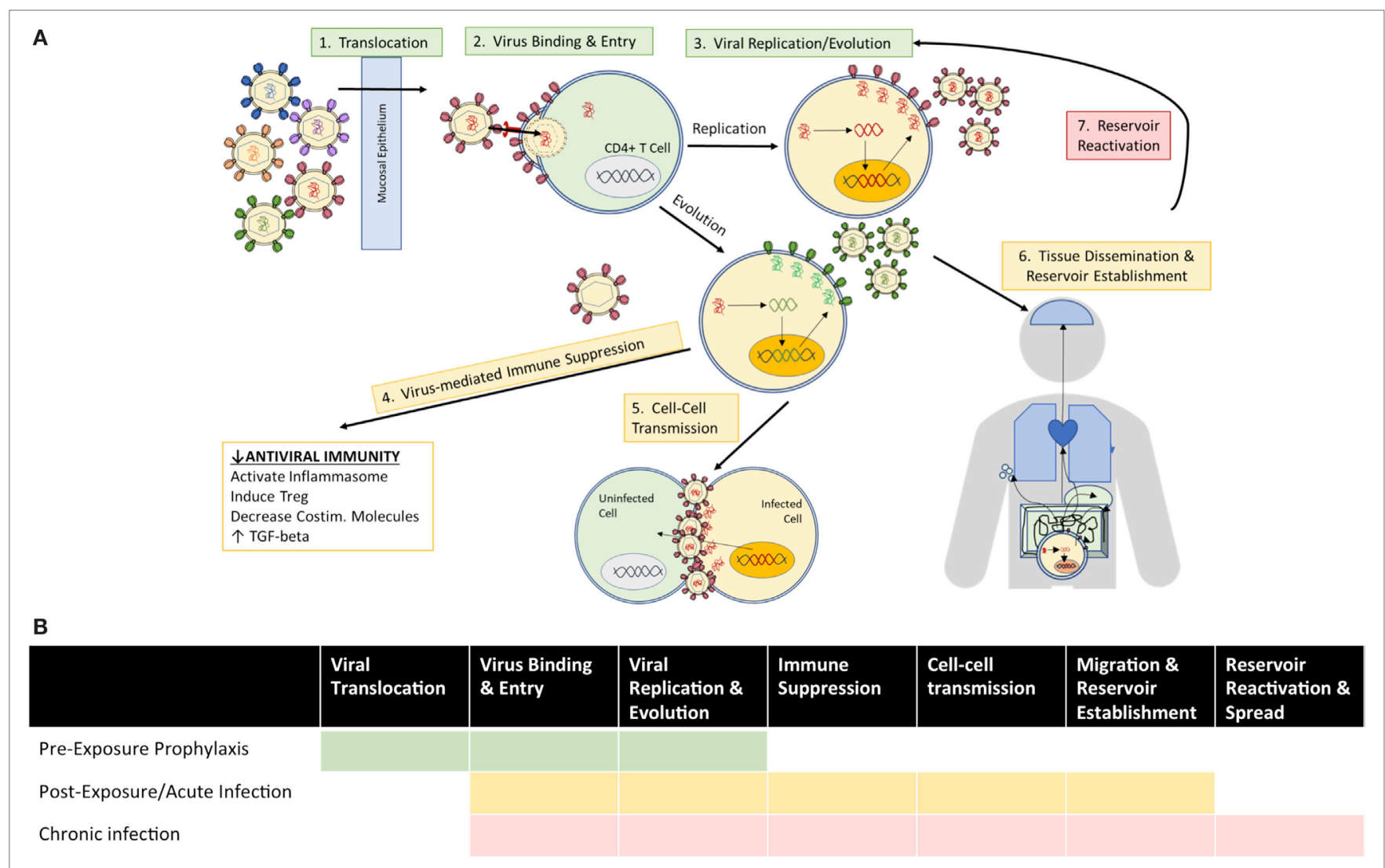

FIGURE 2 | Clinical goals for the use of anti-HIV Abs vary according to (A) mechanisms of viral exposure/infection at the time of administration, and (B) the viral events which therapeutic Abs seek to inhibit among indicated use prior to exposure (green), as postexposure prophylaxis or treatment of acute infection (yellow), and for treatment of chronic infection (red).

adaptive capacity to evade immune-mediated pressure. Viral strains can be described by clade or subtype with viral diversity profiles varying by geographic location, or by neutralization sensitivity designated as very high (tier 1A), above-average (1B), moderate (2), or low (3) sensitivity to Ab-mediated neutralization (pooled plasma samples from four to six clade-matched infected individuals) (52). Clade-matched viral variants are often more sensitive to neutralization by plasma/NAbs from individuals infected by the same clade (52). Thus, the profiling of viral variants endemic to geographical regions could inform the selection of NAbs offering the greatest breadth and potency of neutralization. Ab-based vaccines may function to protect from infection in two ways: (1) neutralization to prevent viral infection in the first place and (2) rapid clearance of virus or virus-infected cells, which will be expanded upon in Section "Enhancing Prophylactic and Therapeutic Potential in Acute Infection: Preventing Viral Reservoir Establishment/Spread." To offer sterilizing immunity, Abs must offer durable protection with sufficient targeting to anatomic sites of exposure to neutralize viruses and prevent infection. To clear virus and virus-infected cells, Abs must be both readily available at therapeutic concentrations and broadly reactive to maintain efficacy against the diversity of viral strains to which an individual might be exposed. Thus, current and potential limitations to the prophylactic use of
bNAbs include: (1) development of viral resistance, (2) requirement for strict regimen adherence, (3) anatomical distribution to sites of exposure, and (4) risk of Ab-dependent enhancement (ADE) of infection.

\section{Viral Resistance}

The arsenal of bNAbs available today targets epitopes spanning a significant portion of the surface of the trimeric HIV Envelope gp140 protein including the V1/V2 loops at the trimer apex, V3 loop glycans, CD4 binding site (CD4bs), gp120-g41 interface, and membrane-proximal external region (MPER) [reviewed in Ref. (53)]. Individual bNAbs vary in neutralization breadth and potency, with some CD4bs targeting bNAbs able to neutralize $>90 \%$ of global circulating HIV-1 strains at low concentrations (54). However, resistance can develop to even the most potent of bNAbs and has indeed been observed in human clinical trials of all three bNAbs tested thus far (14-17). Even among bNAbs targeting the same epitope, different barriers to resistance development may exist from individual to individual and may arise in part from preexisting bNAb-resistant viral strains. Engineering strategies to combat the development of viral resistance reviewed previously (28) include (1) structure-based modifications to increase the breadth, potency (both neutralization and effector function), and half-life of individual bNAbs, (2) combinations of 
TABLE 1 | Summary table of strategies for the improvement of anti-HIV Ab therapy.

\begin{tabular}{|c|c|c|c|c|c|}
\hline Indication & Goal & Mechanism & Limitation & & Improvement Strategies \\
\hline \multirow[t]{9}{*}{ Vaccine } & \multirow[t]{9}{*}{ Block viral entry } & \multirow[t]{9}{*}{ Neutralization } & Viral resistance & $\uparrow$ Breadth and potency & $\begin{array}{l}\text { Structure-based modifications to } \uparrow \\
\text { binding } \\
\text { Broadly neutralizing antibody (bNAb) } \\
\text { cocktails } \\
\text { Bispecific and trispecific bNAbs }\end{array}$ \\
\hline & & & \multirow[t]{5}{*}{$\begin{array}{l}\text { Strict requirement for } \\
\text { adherence to dosing } \\
\text { schedule }\end{array}$} & \multirow[t]{3}{*}{$\uparrow t 1 / 2$} & FC engineering \\
\hline & & & & & Glycan "masking" \\
\hline & & & & & Carrier proteins, peptides, RBCs \\
\hline & & & & $\begin{array}{l}\text { Continuous Ab expression (adeno- } \\
\text { associated virus) }\end{array}$ & $\begin{array}{l}\downarrow \text { Immunogenicity to } \downarrow \text { anti-bNAb } \\
\text { responses }\end{array}$ \\
\hline & & & & & $\begin{array}{l}\text { Targeting multiple tissues for } \\
\text { comprehensive protection } \\
\text { Enable evolution of delivered Abs: } \\
\text { B Cell engineering }\end{array}$ \\
\hline & & & Anatomical distribution & $\uparrow$ Targeting to sites of exposure & $\begin{array}{l}\text { Topical gel delivery } \\
\uparrow \text { Binding to mucosal transporters } \\
\text { Targeted gene delivery }\end{array}$ \\
\hline & & & \multirow{2}{*}{$\begin{array}{l}\text { Risk of Ab-dependent } \\
\text { enhancement }\end{array}$} & $\uparrow$ Breadth and potency & See above \\
\hline & & & & $\begin{array}{l}\text { Maintain protective concentrations } \\
\text { of Abs }\end{array}$ & Dosing schedule or gene delivery \\
\hline \multirow{5}{*}{$\begin{array}{l}\text { Postexposure } \\
\text { prophylaxis and } \\
\text { acute infection }\end{array}$} & \multirow[t]{3}{*}{$\begin{array}{l}\text { Prevent reservoir } \\
\text { establishment }\end{array}$} & \multirow[t]{3}{*}{$\begin{array}{l}\text { Stimulate autologous } \\
\text { antiviral immunity }\end{array}$} & \multirow[t]{3}{*}{$\begin{array}{l}\text { Insufficient protection } \\
\text { after bNAb levels decay }\end{array}$} & $\uparrow$ Viral processing and presentation & $\begin{array}{l}\text { Coadministration of virus/infected cells } \\
\text { (immune complex) }\end{array}$ \\
\hline & & & & $\begin{array}{l}\text { Counter virus-mediated } \\
\text { immunosuppression }\end{array}$ & $\begin{array}{l}\text { Coadministration of immunostimulatory } \\
\text { drugs/Abs targeting characterized } \\
\text { mechanisms }\end{array}$ \\
\hline & & & & Further restrict viral evolutionary space & $\begin{array}{l}\text { Identify Abs targeting "non-survivor" } \\
\text { epitopes }\end{array}$ \\
\hline & $\begin{array}{l}\text { Clear acutely } \\
\text { infected cells }\end{array}$ & $\begin{array}{l}\text { Ab-mediated Effector } \\
\text { functions }\end{array}$ & Low potency? & $\begin{array}{l}\text { Fc engineering for } \mathrm{FcR} / \text { complement } \\
\text { binding } \\
\text { Add toxic payload }\end{array}$ & $\begin{array}{l}\text { Protein/glycoengineering, subclass } \\
\text { switching } \\
\text { Immunotoxin, Ab-drug conjugate }\end{array}$ \\
\hline & $\begin{array}{l}\text { Prevent cell-cell } \\
\text { transmission }\end{array}$ & Unclear & $\begin{array}{l}\text { limited understanding of } \\
\text { mechanism }\end{array}$ & $\begin{array}{l}\text { Elucidate mechanism, especially role of } \\
\text { "neutralizing" epitopes for cell-cell trans }\end{array}$ & $\begin{array}{l}\text { Env conformational changes to define } \\
\text { mission }\end{array}$ \\
\hline \multirow[t]{9}{*}{$\begin{array}{l}\text { Chronic } \\
\text { infection }\end{array}$} & $\begin{array}{l}\text { Suppress viral } \\
\text { replication }\end{array}$ & $\begin{array}{l}\text { All of the above } \\
\text { (AOTA) }\end{array}$ & Resistance & $\begin{array}{l}\text { Combine with antiretroviral therapy (ART } \\
\text { opportunities tot evolution }\end{array}$ & T) to suppress replication and \\
\hline & \multirow[t]{5}{*}{$\begin{array}{l}\text { Target virat } \\
\text { reservoirs }\end{array}$} & \multirow[t]{5}{*}{ AOTA } & \multirow{2}{*}{$\begin{array}{l}\text { Tissue distribution } \\
\text { or Abs and reservoir } \\
\text { accessibility }\end{array}$} & Tissue-targeted delivery & $\begin{array}{l}\text { Ex: liposomal delivery to central } \\
\text { nervous system (CNS) }\end{array}$ \\
\hline & & & & $\begin{array}{l}\text { Cover diverse populations in } \\
\text { compartmentalized tissue }\end{array}$ & $\begin{array}{l}\text { Combine w/additional Abs, ART, } \\
\text { latency-reversing agents }\end{array}$ \\
\hline & & & \multirow{3}{*}{$\begin{array}{l}\text { Low Env expression in } \\
\text { chronic infection }\end{array}$} & \multicolumn{2}{|c|}{ Target Env epitopes of chronic infection } \\
\hline & & & & Target non-viral surface markers & $\begin{array}{l}\text { All potential reservoir cells, including } \\
\text { uninfected (e.g., CD52), or upregulated } \\
\text { on infected cells (e.g., CD32a) }\end{array}$ \\
\hline & & & & Reactivate reservoirs & Add LRAs \\
\hline & \multirow[t]{2}{*}{$\begin{array}{l}\text { Long-term } \\
\text { clearance of } \\
\text { reservoir cells }\end{array}$} & \multirow[t]{2}{*}{$\begin{array}{l}\text { Autologous T-cell- } \\
\text { mediated response }\end{array}$} & $\begin{array}{l}\text { Low cytotoxic } \\
\text { T-lymphocyte (CTL) } \\
\text { response due to } \\
\text { immune suppression }\end{array}$ & $\begin{array}{l}\text { bNAb-based chimeric antigen } \\
\text { receptors (CARs) }\end{array}$ & $\begin{array}{l}\uparrow \text { Clinical safety ( } \downarrow \text { risk of CAR } \\
\text { mediating infection, synthetic biology } \\
\text { "switch" on/off/homing strategies) }\end{array}$ \\
\hline & & & $\begin{array}{l}\text { CTL trafficking } \\
\text { limitations }\end{array}$ & \multicolumn{2}{|c|}{ Investigate/improve bnAb access to CTL sanctuaries } \\
\hline & Virol eradication & AOTA & $\begin{array}{l}\text { Costs of eliminating } \\
\text { reservoir cells in certain } \\
\text { tissues (e.g., CNS) }\end{array}$ & \multicolumn{2}{|c|}{ Pair with gene editing strategics so infected cells may survive } \\
\hline
\end{tabular}

Overlap of therapeutic goals for listed indications (see Figure 2) are not shown in this table. Goals which are targets for multiple indications are grouped under the indication for which they are the primary focus. 
Abs in cocktail therapies, (3) modifying bNAbs to become bispecific, to carry toxic payloads, or to redirect cells in bNAb-based therapies, and (4) altering delivery strategies.

Since the previous review, three additional studies of newly isolated neutralizing Abs have further supported the importance of structural Ab-Env interactions to neutralization breadth and viral evasion. Demonstrating the importance of $\mathrm{Ab}$ binding modes to development of viral resistance, N6, a new bNAb targeting the CD4bs with a novel mode of recognition, does so with amino acid features similar to previously identified mutations to increase the potency of VRC01-class Abs, and demonstrated near-pan neutralization breadth of $98 \%$ of HIV isolates tested, including many isolates resistant to other CD4bs antibodies (55). Defining a new neutralizing epitope, the recently isolated/ characterized bNAb N123-VRC34.01 recognizes a unique trimer-specific, cleavage-dependent epitope at the $\mathrm{N}$ terminus of the gp41 fusion peptide (56). Finally, two recently isolated V2-specific Abs, PGDM1400, and CAP256-VRC26.25, demonstrated unprecedented neutralization potency, protecting against high-dose SHIV challenge at serum Ab concentrations $<0.75 \mu \mathrm{g} /$ $\mathrm{mL}$ for CAP256-VRC26.25-LS (57). In addition, these V2-specific bNAbs exhibited neutralization breadth complementary to that of V3-specific bNAb PGT121 against Clade C viruses, ultimately resulting in $>90 \%$ coverage when used in combination (57).

Recent studies have investigated optimal strategies for combining bNAbs in cocktail therapies (3,58-61), bispecific formats $(62,63)$, and novel tri-specific molecules (64). A combination of only three bNAbs targeting different epitopes has been suggested to be sufficient to cover transmitted viral diversity and evolution based on a study conducted in humanized mice (58) and predictive in silico models of neutralization breadth and potency (59). In an alternative form of combining epitope specificities, the most potent and broad bispecific Ab to date, 10E8v2.0/iMab, demonstrated $100 \%$ neutralization breadth across a 118-member pseudotyped panel with mean inhibitory concentration of $0.002 \mu \mathrm{g} / \mathrm{mL}$ and prevented HIV acquisition in humanized mouse models of infection, demonstrating the synergistic potential of bispecific Abs targeting distinct epitopes (63). In another study, a novel bispecific Ab hinge engineering strategy employing the IgG3 hinge to increase Fab domain flexibility for bivalent binding and to maintain IgG1-Fc function enhanced the in vivo therapeutic activity of bispecific bNAbs (62), emphasizing the synergistic avidity-enhancing effect of intratrimeric, heterobivalent crosslinking of Fab arms to increase $\mathrm{Ab}$ potency (65). In another novel approach, trispecific $\mathrm{Ab}$ molecules containing bNAb specificities against the V1V2 loop trimer apex (PGDM1400), CD4bs (VRC01 and N6), and MPER (10E8v4) were found to mediate increased breadth and potency compared to individual parental bNAbs both in vitro and in SHIV challenge models (64). The authors speculated that the tri-specific bNAb may have decreased risk of viral resistance compared to cocktail strategies where differences in component bNAb half-lives may decrease selective pressure (64). However, whether these trimeric molecules engage multiple epitopes simultaneously and/or otherwise confer added benefit over a cocktail consisting of the same three bNAbs remains to be determined.
Beyond development of viral resistance within an individual to bNAb therapy, implications of widespread use of bNAbs as prevention may influence the composition and evolutionary dynamics of worldwide HIV strains. HIV drug resistance is increasingly observed due to poor patient adherence enabling the development of resistance, and subsequent transmission of newly developed drug-resistant strains (66). Similar potential for the development of bNAb-resistant "super-strains" of HIV exists, as bNAb-resistant strains often coexist or arise within individuals from whom bNAbs were isolated. Trade-offs between viral evasion and fitness costs incurred by some resistance mutations (67-70) may mitigate these concerns. However, resistance mutations without fitness costs $(70,71)$ and the development of compensatory mutations to restore fitness have also been described (67), and antibodies vary with respect to sensitivity to evasion and ease of compensation. Combination strategies such as the cocktails or multispecific molecules described above may best prevent the development of "super-strains" of HIV by further restricting the viral evolutionary landscape. Thus, strategies to optimize bNAb administration and pharmacokinetics to make treatment regimens manageable and supportive of strong treatment adherence will be critical to avoid the development of bNAb-resistance on a more global scale.

\section{Alleviating Requirements for Regimen Adherence}

Because viral rebound quickly occurs upon bNAb decay and renewed replication enables opportunities for viral evolution, protective bNAb dosing schedules must be strictly followed to prevent both viremia and viral resistance. Two methods to decrease the frequency of dosing are (1) increasing the serum half-life of bNAbs and (2) bNAb gene delivery for continuous in vivo expression.

\section{Increasing Serum Half-Life of bNAbs}

Interestingly, bNAb levels decayed more quickly in $\mathrm{HIV}(+)$ individuals as compared to controls in human clinical trials, potentially due to the formation of Ab-virus immune complexes in infected individuals that are more rapidly cleared from circulation. For bNAbs to offer prevention potential, and to avoid the development of resistance, serum half-life would need to be long enough to maintain protective concentrations at reasonable dosing schedules. Fc engineering strategies to increase the half-life of bNAbs have been described [reviewed in Ref. $(28,72)$ ], including studies of the VRC01-LS variant which demonstrated a threefold longer serum half-life and increased translocation to mucosal tissues, ultimately leading to improved potency and protection against high-dose rectal challenge in non-human primates $(29,73,74)$. VRC01-LS (M428L and N434S) $(29,74)$ has now advanced into Phase I clinical trials (NCT02797171, NCT02840474, NCT02599896, NCT02256631).

\section{Continuous Protection via Gene Delivery: In Vivo Expression of bNAbs}

In an indirect way to extend the lifetime of bNAb therapy, gene delivery has been increasingly explored to achieve durable $\mathrm{Ab}$ 
concentrations, most prominently by adeno-associated virus (AAV) vectors [reviewed in Ref. (75)]. Historically, AAV deliverybased gene therapy has demonstrated safety and efficacy in both macaques (76-79) and humans (80-85) for a variety of diseases, and has become the first clinically and government-approved gene therapy in Europe $(86,87)$. Within the realm of HIV, AAVdelivered HIV-specific bNAbs and Ab-like molecules such as CD4-Ig have demonstrated sterilizing and durable protection against SIV/SHIV infection in macaques $(73,88-90)$ and HIV infection in humanized mice $(4,91)$, and are now undergoing Phase I human clinical trials to evaluate safety, deliverability, and potential efficacy in England (NCT01937455).

Current limitations to bNAb gene delivery include the development of anti-bNAb responses and the virus independence of bNAb expression. First, several studies of AAV-delivered bNAbs to macaques have demonstrated the development of anti-bNAb responses $(73,88,90,92)$, despite "rhesus-ization" of bNAbs and addition of immunosuppressive therapy, potentially due to immune-stimulating effects of the AAV itself which can trigger innate pattern recognition receptors and toll-like receptors or engage preexisting cellular (93) or humoral (94) immunity. Side-by-side comparisons of anti-bNAb responses in passively transferred bNAbs vs. AAV-delivered bNAb treatment have been proposed to delineate immunogenic contributions from AAV vs. $\mathrm{Ab}$ (75). Engineering strategies to decrease the immunogenicity of AAV capsids and coadministration of immunosuppressive agents (cyclosporine, T-cell inhibition, IVIG, corticosteroid) have been proposed and shown promise (75). However, immunosuppressive agents may also decrease bNAb Fc-mediated effector function and the development of autologous antiviral responses, placing the bulk of protection on neutralization. Thus, studies to determine the costs and benefits of adding immunosuppressive agents to AAV-delivery regimens are warranted.

Second, current AAV-delivery of bNAbs results in bNAb expression independent of viral trafficking, replication, and evolution, and therefore (1) may not be ideally distributed for prevention of infection/reservoir establishment and (2) cannot respond to changes in the viral population. Intramuscular delivery of vectored gene therapy to skeletal muscle is most extensively studied thanks to muscle tissue's amenability to long-term gene expression, abundant vascular supply for quick transport to the systemic circulation, and ease of accessibility (95). However, vectored gene delivery to additional tissues including the liver, brain, spinal canal, skin, and eyes have been described (95). Targeted gene delivery to these tissues may be especially useful if protective $\mathrm{Ab}$ concentrations in these tissues are not possible from circulation alone.

However, such bNAb-expressing tissues are unable to respond to viral evolution, and may become less useful as viral populations develop resistance to the administered $\mathrm{Ab}$. Thus, strategic delivery of bNAb genes to B-cells for integration at native BCR loci (gene targeting into the Igh locus) under the normal regulation of heavy-chain expression, Ab class-switching, and somatic mutation may offer the added benefit of coevolution with viral populations. A similar technology of in vivo bNAbas-BCR evolution has been used in HIV Env immunogen studies in transgenic knock-in mice containing B-cells expressing germline heavy chain variants of VRC01-class Abs (96-98), which were successfully activated/expanded and underwent somatic hypermutation in response to various Env immunogen regimens. Viral challenge of similarly generated knock-in mice containing genes for mature bNAbs as BCRs may demonstrate proof-of-concept for bNAb-based BCR engineering. Clinical translation of such a strategy could parallel chimeric antigen receptor (CAR) T-cell procedures, whereby B-cells could be extracted from a patient and engineered ex vivo to expressed bNAb-based BCRs prior to reinfusion. Investigations into efficient and targeted IgH knock-in would be critical to this approach and increased understanding of B-cell differentiation and subtypes, BCR editing, and tolerance checkpoints would be beneficial. Additionally, switchable gene expression may be desired to prevent unchecked expansion/growth. While this ability to coevolve may not ultimately provide any benefit, natural infection histories provide both reasons for optimism and pessimism. In favor of the optimistic possibilities, the ability of bnAbs to improve autologous antibody neutralization potency, and their ability to collaborate with other lineages for beneficial outcomes suggests that the ability to adapt over time could be advantageous.

\section{Targeting Anatomical Sites of Exposure}

One probit analysis of bNAb-treated macaques suggested that a serum level of 100 times the bNAb IC50 affords 50\% protection against intrarectal infection (41), a level that is estimated to be attainable by biannual passive $\mathrm{Ab}$ injections given the serum $\mathrm{Ab}$ levels and half-lives of VRC01 and 3BNC117 in human clinical trials (25). In an SHIV macaque study, IV infusion of $2 \mathrm{mg} / \mathrm{kg}$ PGT121 completely protected subjects from intravaginal challenge with $5 \times 10^{4}$ TCID50 SHIV-SF162P3, with no detectable viral RNA or DNA found in distal tissue sites by day 10 after challenge (99). However, concentrating Abs at the sites of viral exposure may allow even lower doses to be protective. Because viral exposure often occurs at mucous membranes including the rectal and vaginal tracts, the presence of bNAbs at mucosal sites to mediate immune exclusion may improve protection. Therapeutic administration and $\mathrm{Ab}$ engineering strategies to improve bNAb use for mucosal immunity were described previously (28) and included topical gel delivery, Fc engineering to enhance binding to FcRn and pIgR at mucosal sites, and designing IgA and chimeric IgGA variants of bNAbs. In addition, some of the strategies described above such as targeted AAV-delivery of $\mathrm{bNAb}$ genes to specific tissue sites or BCR engineering to express class-switched IgA versions of bNAbs may be beneficial. Studies have found contrasting evidence for (100-103) and against (104) a role for bNAbs, formatted as various isotypes, in preventing transepithelial migration. The reason for this discrepancy is unknown but may be related to the utilization of older-generation or less potent bNAbs in the prior studies (2F5, $2 \mathrm{G} 12,4 \mathrm{E} 10)$, whereas the most recent studies investigate newergeneration, more potent bNAbs. In that study of bNAbs targeting a wide range of epitopes, bNAbs did not block the transcytosis of either cell-free or cell-associated HIV-1 in vitro and instead relied upon neutralization to decrease the infectivity of transcytosed viruses (105). Thus, increasing the local concentration and 
neutralization breadth and potency of bNAbs at mucosal sites may enhance protection against mucosal infection.

\section{Potential Risks: ADE of Infection}

Thus far, ADE of HIV infection has only been observed in vitro and grouped into complement- (106-108), Fc Receptor (FcR)(109-112), and conformationally mediated $(113,114)$ mechanisms which ultimately facilitate virus internalization or receptor-independent virus-cell membrane fusion [reviewed in Ref. $(115,116)]$. In addition, antibody-virus immune complexes could increase trafficking of infectious virions to lymph nodes, thereby amplifying rates of viral infection and replication. While debate exists over whether ADE occurs in natural HIV infection, the presence of enhancing Abs have been correlated with disease progression in some studies of sera from HIV-infected individuals $(117,118)$ [but not others (119)] and suggested to explain increased rates of infection in individuals with relatively low $\mathrm{Ab}$ responses in vaccine trials (120) and correlations of particular FcR genotypes characterized by stronger Fc-binding affinities with higher infection risk $(121,122)$. Both nnAb and neutralizing $\mathrm{Ab}$ at subneutralizing concentrations can enhance infection in vitro (109), and epitope specificity does not necessarily determine an Ab's potential for ADE (115). Thus, maintaining protective concentrations of bNAbs via repeated dosing or continuous expression (AAV) may be especially critical to decrease the risk of ADE.

\section{ENHANCING PROPHYLACTIC AND THERAPEUTIC POTENTIAL IN ACUTE INFECTION: PREVENTING VIRAL RESERVOIR ESTABLISHMENT/SPREAD}

After exposure, bNAbs may be used as prophylaxis to prevent the establishment and spread of viral reservoirs [reviewed in Ref. $(123,124)]$. Successful elicitation or administration of HIV-specific Abs in macaque models of acute SHIV challenge and infection have correlated with reduced acute viremia and limited reservoir seeding $(46,125,126)$. The window for postexposure prophylaxis has been estimated to be as short as $24 \mathrm{~h}$ to block infection by cell-free virus in macaque models of SHIV infection $(127,128)$ and within the first 9-10 days to limit viral reservoir seeding and spread (129). Resistance continues to be a major concern for all of the described bNAb indications in this review, but may be especially relevant in postexposure settings where autologous viral populations may be screened for preexisting resistance to bNAbs. Mucosal barriers and/or autologous immune responses often limit the diversity of transmitted/founder (T/F) strains; in one study, $80 \%$ of individuals infected through heterosexual and $60 \%$ through homosexual contact were found to have a single founder virus strain (130). Thus, the low viral diversity present in acute postexposure settings render it a particularly useful time at which to screen viral populations to inform the choice of $\mathrm{bNAb}(\mathrm{s})$ therapy. Efforts to adequately sample viral diversity later during chronic infection become more difficult as latent reservoirs are established and thus viral sensitivity screening may be less useful at later time points.
In addition to the previously described goals to neutralize virus to prevent initial infection, postexposure prophylactic use of Abs additionally seeks to limit reservoir seeding and spread. Enhancing the ability of mAb therapies to (1) increase autologous immune responses and (2) target acutely infected cells represent two strategies by which to accomplish this goal.

\section{Increasing Protection by Influencing the Autologous Adaptive Immune Response}

Both neutralizing $\mathrm{Ab}$ and $\mathrm{nnAbs}$ depend upon Fc-mediated effector functions for antiviral activity in vivo $(131,132)$. Through the Fc portion, elicitation of even nnAb responses offers therapeutic utility, demonstrating protective effects in both vaccination $(121,133)$ and passive transfer studies $(44,134,135)$. Stimulation of autologous $\mathrm{Ab}$ responses, whether neutralizing or not, thus remains a promising means by which to generate durable effects from $\mathrm{Ab}$ therapy.

Broadly neutralizing antibody therapy has been associated with enhanced autologous antiviral immune responses in both human $(19)$ and macaque $(13,34,35)$ studies. Proposed mechanisms for this observed effect include (1) facilitation of viral processing and presentation, (2) potential immune-stimulating effects in an otherwise suppressed adaptive immune background conferred by HIV infection, and (3) restriction of viral evolutionary space by both administered bNAbs and elicited autologous Abs. Efforts to increase autologous $\mathrm{Ab}$ responses may thus focus upon enhancing each of these mechanisms.

\section{Enhancing Viral Processing and Presentation}

Increasing the effector function capacity of anti-HIV Abs by Fc engineering to skew binding toward particular Fc receptors represents one mechanism by which to engage and stimulate endogenous immunity, and has been previously reviewed in Ref. $(28,72)$. Beyond engineering bNAb molecules, adjunctive coadministration of envelope, virus or infected cells with Abs in immune complexes can engage FcyRs on antigen-presenting cells to facilitate antigen internalization and enhance APC activation and presentation, ultimately "boosting" endogenous antiviral immunity [reviewed in Ref. (136)]. Although one study found that opsonization of HIV-1 with polyclonal anti-HIV IgGs was associated with decreased dendritic cell activity (137), further investigations of Abs of varying neutralization potency formatted as different isotypes have been proposed to clarify the generalizability of that study (136). In another study, administration of HIV-1 gp120 Env and a CD4bs mAb resulted in enhanced neutralization potency of elicited humoral responses in mice (138). Notably, Fab-mediated effects that resulted in greater presentation of particular epitopes in the Ab-bound immune complex were determined to be at least partially responsible for the increased neutralization potency of the elicited antibody response (139-141). Additional parameters to be investigated in the use of immune complexes to stimulate endogenous antiviral immunity include antigen format (soluble vs. virus vs. infected cell), Ab format (neutralization capacity, isotype, Fc variants), ideal ratios of Ab:Ag to form complexes, and routes of administration (136). 


\section{Combatting Viral-Mediated Suppression of the Antiviral Immune Response during Acute HIV Infection}

Acute HIV infection is characterized by early suppression of antiviral immune responses to support viral growth and spread. Mechanismsforthisantiviral-specificimmunosuppressioninclude increased activation of the NLRX1 inflammasome (129, 142), which negatively regulates interferon-stimulated antiviral genes, and increased secretion of TGF-beta (129) that inhibits adaptive immune responses. In addition, viral interactions can induce early activation of regulatory T-cells $(143,144)$, and increase the expression of inhibitory T-cell markers PD-1 and CTLA-4 $(145,146)$. The effect of these immunosuppressive mechanisms on Ab-mediated effector function remains to be determined (124), but likely decreases the efficiency with which Ab-mediated stimulation of autologous immune responses arise. Combination with immunostimulatory drugs and antibodies targeting these specific mechanisms of immunosuppression may thereby increase the development of autologous antiviral immune responses, but may be a double-edged sword as there is a concomitantly increased risk of enhancing the development of anti-bNAb responses or the pool of CD4+ T-cells available for infection. In vivo studies of such approaches will be especially critical to determine the utility and/or feasibility of this approach.

\section{Identifying Abs Targeting "Non-Survivor" Epitopes: Limiting Viral Evolution}

Finally, autologous $\mathrm{Ab}$ responses may have antiviral effects by limiting the space for viral evolution through the targeting of "non-survivor" epitopes, regions in which resistance mutations incur survival costs or complete lethality [reviewed in Ref. (43)]. These epitopes can be distinct from epitopes recognized by bNAbs, against which resistance mutations commonly develop and are often contemporaneous with the presence of the bNAb in individuals from which they are isolated. Thus neutralizing epitopes identified thus far are largely "survivor" epitopes and a recent review has raised the concern of "survivor bias" in present studies of protective humoral responses (43). Potential non-survivor epitopes include functionally critical regions targeted by non-neutralizing epitopes that become exposed upon conformational changes including CD4-inducible epitopes (147) and gp41 epitopes like the fusion peptide $(46,56)$ : passive transfer of nnAbs targeting these regions successfully decreased the number of transmitted/founder viruses from high-dose SHIV challenge in macaques (46).

\section{Clearing Acutely Infected Cells}

Acutely infected cells must be cleared early to prevent the establishment of reservoirs. Toward this goal, Abs can engage innate effector cells through the Fc portion to stimulate Ab-dependent cellular cytotoxicity (ADCC), Ab-dependent cellular phagocytosis (ADCP), or complement-dependent cytotoxicity (CDC). To further improve Abs' capacity for cell-clearance, bNAbs may be engineered for enhanced Fc-mediated effector functions [described previously in Ref. $(28,72)$ ] or modified through the conjugation of toxic payloads [reviewed in Ref. (148)].

\section{Enhancing Ab Effector Function}

Engineering strategies to augment Fc-mediated effector functions of $\operatorname{HIV}$ Abs were described in detail previously $(28,72)$, including IgG subclass switching and protein/glycoengineering to bias Fc receptor/complement component binding profiles. Multiple Fc-engineered mAbs have now entered and/or demonstrated safety and efficacy in various phases of clinical trials as well [reviewed in Ref. (149)]. The results of these studies will inform the capacity of in vitro and animal models of Fc-engineered $\mathrm{Ab}$ function to predict effector function in humans. They may further help to model the relationships between changes in $\mathrm{Ab}-\mathrm{Ag}$ binding affinity, Fc-Fc receptor binding affinities, and clinically significant differences in effector functions in humans as has been described in animal models (150-152), and to determine whether there is an optimal Fc receptor binding affinity profile to elicit particular effector functions.

\section{Immunotoxins}

In acute infection, potent, transient cytotoxicity may be sufficient to inhibit reservoir establishment. Thus, conjugation of Abs with more toxic payloads such as bacterial exotoxins may be tolerable as a short-term solution to ensure rapid and complete cytotoxicity in place of or in addition to Fc-mediated effector functions to treat acute infection. In contrast, $\mathrm{Ab}$-based immunotherapies that are more amenable to long-term use with more durable effects will be discussed in Section "Enhancing Therapeutic Potential for Chronic Infection" to treat chronic infection. In addition, viral Env has been suggested to be more highly expressed during early infection (153), making viral Env-targeting Abs potentially more useful as targeting agents during this period.

In one study, HIV-specific recombinant immunotoxin (RIT) employing Pseudomonas exotoxin A, 3B3-PE38, in combination with ART significantly decreased the number of HIV RNAproducing cells compared to ART alone in BLT humanized mouse models of HIV infection (154), although a potential for toxin immunogenicity and viral resistance were cited as limitations to chronic use of the immunotoxin. In a recent study testing a panel of HIV-specific mAbs as RITs, epitope specificity was found to correlate most with cytotoxicity against H9/NL4-2 cells (HIV Env expressing cell line), as compared to binding/neutralization potency (155). The most effective RIT employed mAbs targeting a non-neutralizing epitope in the gp41 loop region, which lies close to the plasma membrane and may thus allow the toxin to enter the cell more effectively $(155,156)$. Combination with soluble CD4 (sCD4) further increased the cytotoxicity of gp41 loop-targeting RITs, likely due to increased exposure of the gp41 epitope after sCD4 binding induced conformational changes in Env and increased internalization of Env-bound RITs in the presence of sCD4 $(155,157)$.

In vivo studies of another gp41-specific RIT employing a Ricin A chain (RAC) toxin, 7B2-RAC, also demonstrated efficacy in SHIV-infected macaques prior to the development of antidrug Abs after 2-3 weeks due to RIT immunogenicity (158). In the same study, to combat this observed immunogenicity, the authors PEGylated RITs prior to use in mouse models of HIV, which resulted in lower antidrug Ab levels in a subset of mice (158). 
However, additional methods to decrease RIT immunogenicity [reviewed in Ref. (159)] may be required. In addition, cytotoxic payloads with decreased immunogenicity may be used instead of protein toxins to make antibody-drug conjugates (ADCs). In the SHIV macaque study of 7B2-RAC, ADCs employing existing small molecule cytotoxic drugs were also tested but were less efficacious than the RIT, likely because their drug toxicities were $1-\log$ less potent than the RAC toxin (158). Thus, ADCs may become more competitive as more potent cytotoxic small molecule drugs are developed to rival recombinant toxins.

\section{Preventing Cell-Cell Transmission}

In addition to infection by free HIV, cells may become infected by horizontal transmission from other infected cells [reviewed in Ref. (160)]. The frequency with which cell-cell transmission occurs in vivo is unknown, but infection by cell-associated virus has been demonstrated in Macaque models of infection by SHIV-infected splenocytes (161), and suggested by studies of mother-to-child transmission of HIV during pregnancy, labor, and delivery [reviewed in Ref. (162)] and by spatial segregation of viral sequences (163). In addition, cell-cell transmission of virus was found to be more efficient than infection by free virus in vitro (164) and could lead to multiple infections of a single cell (165). A recent study found that different bNAbs exhibited $\mathrm{Ab}$ - and viral strain-dependent capacities to inhibit cell-cell transmission: for non-CD4bs-epitope targeting Abs, mAbs with increased potency of free virus neutralization exhibited greater losses in neutralization activity of cell-cell transmission, suggesting that optimal binding characteristics for free virus neutralization differ from those for cell-cell transmission neutralization (166). In another recent macaque study, bNAb PGT121 administered at protective concentrations against cellfree virus were only partially efficacious (3/6 macaques) at protecting from SHIV-infected splenocyte challenge (161). Studies to elucidate the mechanisms by which cell-cell transmission occurs and conformational differences in Env structure during transmission (167) would be beneficial to defining a strategy to improve this type of neutralization.

\section{ENHANCING THERAPEUTIC POTENTIAL FOR CHRONIC INFECTION}

Current therapy for chronic infection aims to suppress viremia to prevent symptoms from virus-stimulated immune activation and to prevent the growth/spread of viral reservoirs to preserve CD4+ T-cells. Today, ART largely accomplishes these goals to maintain low viral loads by blocking viral replication, but its use is limited by long-term end-organ drug toxicities, a strict requirement for treatment regimen adherence, and the development of viral resistance (168). In addition, persistent low-level viremia can remain even under ART treatment (169-171), potentially from cells infected prior to therapy initiation or in tissues with poor drug penetration (172) or residual virus replication in latently infected cells $(169,173,174)$. Thus, therapeutic alternatives for chronic HIV infection that may lessen the burden or address limitations of ART are desired.
Encouraging results for the utility of bNAbs as treatment for chronic infection [reviewed in Ref. $(26,168)$ ] from recent human clinical trials include effective suppression of circulating free virus in individuals harboring bNAb-sensitive strains $(15,17)$, delayed viral rebound after ART treatment interruption $(14,19)$ suggesting reduction of cell-associated virus or viral reservoir size (32), elicitation of host immune responses (19), and suppression of HIV replication in reservoir cells (175). Most of these results were found in a subset of treated individuals, dependent upon the preexisting resistance of circulating/reservoir strains, and in all cases viremia rapidly rebounded upon bNAb decay or cessation. Thus, strategies to combat both preexisting and de novo development of viral resistance remain a target of $\mathrm{Ab}$ therapy for chronic infection.

\section{Combination with ARTs}

Given the relative success of existing ART in treating chronic HIV infection, the comparison between bNAb therapy vs. ART or the benefit of adding bNAb therapy to ART has garnered interest. The potential for bNAbs to enhance the effects of ART lies in the ability to address residual sources of viral replication and further limit the development of viral resistance. One study found that the combination of bNAbs with ART was no better than treatment with ART alone in macaque models of SHIV infection (126), likely due to the already low level of viral replication and in some cases undetectable viremia of subjects undergoing ART alone in the observed period. On the other hand, ART significantly limits, but may not completely prevent, viral evolution of both circulating and tissue reservoir populations $(176,177)$. Thus bNAbs may be especially useful in combination with ART, which removes the major limitation of evolving resistance. In addition, the tissue distribution of ART and bNAbs or bNAb-based therapies may complement each other, with bNAbs "cleaning up" after persistent viral replication from virus-infected cells in tissue compartments receiving subtherapeutic levels of ART, such as lymph node germinal centers which may be more readily accessible to Ab- or Ab-based bispecific molecules interacting with APCs or T-cells (168). On the other hand, ART-mediated suppression of viral replication decreases the expression of Env epitopes on the surface of infected cells, and may thereby require more potent bNAbs or Abs targeting non-Env markers of infection.

\section{Targeting Viral Reservoirs: Accessing Tissues and Identifying Cell Targets}

Distinguishing which tissues and cell types can support viral reactivation and/or contribute to AIDS progression is critical to defining the extent of viral eradication desired/needed and the development of strategies with which to target cellular reservoirs. For viral remission, accepting persistent viral latency in some reservoirs with low reactivation potential and/or high costs of cellular/tissue damage may be acceptable. Multiple studies have suggested that decreasing the size of the viral reservoir delays viral rebound after ART is stopped (178-180), with one modeling study suggesting that a four-log reduction of the simulated $3 \times 10^{5} \mathrm{mem}$ ber reservoir size comparable to observed reservoirs of $10^{5}-10^{7}$ (181) could prevent viral rebound after ART altogether (182). 


\section{Tissue Reservoirs: Distribution and Accessibility}

Viral reservoirs may establish in multiple tissue sites (183) and cell types (184), making sufficient access to and efficacy in reservoir tissue sites and identification of target cells key components of combatting latent HIV infection. The primary site for viral replication occurs in central lymphoid tissues $(18,19)$, with lymph nodes, spleen, and GI tract lymphoid tissue harboring the largest numbers of HIV-infected cells (183). Unfortunately, these secondary lymphoid organs can act as pharmacologic sanctuaries limiting ART concentrations and viral suppression: lower concentrations of ART in lymph nodes (vs. blood) have been associated with persistent viral replication within lymph nodes (185). However, viral RNA/DNA has been found in nearly all tissues, including immune-privileged sites such as the central nervous system (CNS), testes, and placenta (183). Mixed evidence for compartmentalization, or differences in viral populations among different tissues and in circulation, exists (183) and may indicate a need for combination therapy with additional Abs, ART, or latency reversing agents (LRAs) with wider tissue penetration or more tissue-specific administration/targeting, such as liposomal delivery of drugs to the CNS [reviewed in Ref. (186)].

\section{Reservoir Cell Types: Surface Markers of Infection}

Within individual tissues, CD4+ T-cells comprise the majority of cell types harboring latent virus but viral DNA has been found in non-CD4+ T-cells [reviewed in Ref. (187)], including CD4-/ CD8- T-cells (188), macrophages [reviewed in Ref. (189)], monocytes, tissue macrophages (190), and follicular dendritic cells $(191,192)$. Identifying reservoir cells can be challenging due to their relative quiescence and transient expression of low levels of viral antigens. Expression of HIV Env may additionally be different in latent cells as compared to cells with active viral replication. Given the instability of trimeric Env, non-neutralizing epitopes accessible on monomeric gp140 or gp41 stumps have been suggested to be displayed on the surface of infected cells over time (193). Thus, epitope targets of therapeutic HIV mAbs for chronic infection may vary significantly from those for the acute postexposure setting, reflective of the differing goals of targeting latent cells vs. active virus.

One strategy to combat this challenge is to identify nonviral surface markers that are expressed, or preferably upregulated, on infected cells. In an extreme example, CD52 expression on a wide breadth of immune cells capable of serving as reservoirs during HIV infection-nearly all T-cells, B-cells, and plasmacytoid dendritic cells - may be targeted by anti-CD52 Abs to deplete reservoir cells $(194,195)$, but uninfected immune cells may also be affected. Instead, Abs recognizing markers suggested to be upregulated by infection (196) may preferentially target reservoir cells and ameliorate some of the side effects expected from more general immune depletion strategies. In addition, these Abs may be used to guide the delivery of more toxic payloads in Ab-based therapies such as immunotoxins, bispecific T-cell engagers, or CARs in cellular therapy.

In another approach, LRAs may be used to re-activate cells and increase expression of viral antigens. However, the reactivation of virus increases the production of viral particles and risk of increasing cellular infection rates, and therefore must be balanced with potent elimination therapy, including bNAbs, in "shock and kill" strategies to quickly and efficiently eliminate reactivated cells. Coadministration of bNAbs with three viral inducers in humanized mice reduced the proportion of mice with viral rebound after Ab levels decayed, whereas Abs alone or combinations of bNAbs with a single inducer failed to affect viral rebound rates (132). Thus, strategies to optimize the combinations of Abs and inducers $(25,197)$ or to increase the potency or long-term effects (e.g., autologous immune responses) of Abs as elimination therapy may be necessary to maintain viral suppression after the decay of therapeutic Ab.

\section{Long-term Clearance of Infected Reservoir Cells: Cellular Therapy}

Natural Abs rely upon Fc-mediated effector function to clear infected cells. However, Ab-mediated effector functions may be less active or unavailable in infected tissue reservoirs with immunosuppressed or immune-privileged microenvironments. Thus, an alternative strategy to increase the potency with which Abs may destroy infected cells focuses upon addressing the limitations of T-cell-mediated responses. Effective cytotoxic T-cell responses have been associated with viral control in studies of relatively rare long-term non-progressors $(198,199)$ and HIVexposed seronegative individuals (200). Similarly, persistent viral suppression after Ab therapy in a subset of SHIV-infected macaques ( 3 out of 18 ) was associated with improved host virusspecific cytotoxic T-lymphocyte (CTL) responses (13). Thus, anti-HIV Abs may be used to augment or complement cellular immune responses for long-term term viral control.

\section{Engineering for Enhanced Cytotoxic Responses: CAR Cells}

Rather than relying upon the natural development of host CTL responses, an alternative strategy employs HIV-specific Abs to re-direct T-cells toward HIV-infected cells. Promising bispecific T-cell engaging molecules $(201,202)$ and CAR T-cells $(203,204)$ have been previously reviewed (28) and are increasingly viable given the recent advent of the FDA's first recommendation for clinical approval of a CAR T-cell therapy (Novartis CTL019). Strategies with which to enhance the cytotoxic activity of bispecific T-cell engaging molecules and HIV-specific CAR T-cell approaches were described previously (28). This review thus focuses upon strategies with which to improve the clinical safety and efficacy of CAR therapies for HIV infection.

One concern is that HIV-binding CARs may render T-cells more susceptible to infection, especially CD4ל-based CARs (205). Thus, strategies to protect anti-HIV CAR-modified cells include the cotransduction/expression of fusion inhibitors $(206,207)$, and knock-out/knock-down of CCR5 expression (208-211). A second concern is that the necessary expansion of engineered T-cells can lead to exhaustion and loss of activity (205), compounded by the fact that T-cells often already express inhibitory markers associated with exhaustion during chronic HIV infection $(145,146)$. To combat this predisposition for T-cell exhaustion, stem/progenitor cells may be modified with 
CARs instead with the added benefits of the generation of more durable and potentially diversified cell types bearing the CAR, as well as the built-in thymic immune tolerance checkpoints through which T-cells developing from stem/progenitor cells must proceed (205). Hematopoietic stem/progenitor cells modified with a CD4 $\zeta$-CAR in humanized mouse models of HIV infection successfully differentiated and maintained CAR expression in multiple cell types, including T-cells and NK-cells, and reduced viral loads in treated animals (204).

More general concerns with the clinical use of cellular therapies as a class have been reviewed (212), and include the potential for cytokine storm from mass T-cell activation and cytotoxicity $(213,214)$, cellular transformation from genomic integration of viral vectors due to insertional mutagenesis (215), and autoreactivity (216). Strategies to mitigate these risks employ synthetic biology tools [reviewed in Ref. (217)] such as inducible suicide or "switch" strategies to induce apoptosis of CAR T-cells $(218,219)$, feedback-based "pause" switches (220), and preferential homing/activation based on "logic gate" requirements for engagement of multiple antigens (221-225).

\section{Complementing Autologous T-Cell Responses: Access to T-Cell Sanctuaries}

Cytotoxic T-lymphocyte trafficking patterns may limit their ability to access all viral reservoir sites (226). In one macaque study of SIV infection, the viral reservoir population of elite controllers was found to differ from that of progressors: elite controller macaques largely harbored virus in follicular helper T-cells $\left(\mathrm{T}_{\mathrm{FH}}\right)$ whereas progressor monkeys harbored virus across a wider breadth of T-cell subtypes (226), suggesting that protective CTL responses may not be able to access $\mathrm{T}_{\mathrm{FH}}$ reservoir cells. Thus the ability of bNAbs (or other anti-HIV Abs) to access and clear reservoir cells from CTL sanctuaries (such as $\mathrm{T}_{\mathrm{FH}} \mathrm{S}$ in $\mathrm{B}$-cell follicles) is of particular interest (25).

\section{Potential for a True "Cure": Viral Eradication vs. Reservoir Eradication}

A true HIV "cure" would entail the complete eradication of virus from an infected individual, including all latent reservoir cells. By this definition, an extremely potent form of "shock-and-kill" strategies would likely be necessary to expose and eliminate all reservoir cells using HIV mAbs. In addition, the tangled link between viral eradication and tissue reservoir cell eradication poses a potential cost to these types of immunotherapy, especially in cases such as CNS reservoirs, where cells have limited regeneration capacity but make vital functional contributions to quality of life (186). Thus, alternative gene-editing approaches to specifically excise integrated viral DNA from infected cells (227) may be needed in combination with mAb-based approaches to achieve such a "cure."

In an alternative definition, a "cure" may be functionally described as undetectable levels of virus in the absence of additional therapy. Such a "functional cure" may be more feasible by the Ab-based strategies described above, with particular emphasis on the life-long delivery of immunotherapy (gene or cellular therapy) or the stimulation of sufficiently broad and potent autologous immune responses for life-long immune surveillance.

\section{CONCLUSION}

Preclinical studies of bNAbs to prevent and treat SHIV infection in macaques and Phase I human clinical trials demonstrating reduction of viral load and even reservoir size support the clinical utility and potential of bNAbs for prevention, postexposure prophylaxis, and therapy of acute and chronic infection. Observed and potential limitations of bNAbs noted thus far in these recent studies include the selection of resistant viral populations, immunogenicity resulting in the development of antidrug $(\mathrm{Ab})$ responses, and the potentially toxic elimination of reservoir cells in regenerationlimited tissues. Opportunities to improve the utility of HIV Abs address these challenges and build upon each other as the timing/ stage of infection progresses. Before exposure, bNAbs' ability to prevent infection by neutralization may be improved by increasing serum half-life to necessitate less frequent administration, delivering genes for durable in vivo expression, and targeting bNAbs to sites of exposure. After exposure and/or in the setting of acute infection, bNAb use to prevent/reduce viral reservoir establishment and spread may be enhanced by increasing the potency with which autologous adaptive immune responses are stimulated, clearing acutely infected cells, and preventing cell-cell transmission of virus. In the setting of chronic infection, bNAbs may better mediate viral remission in combination with ARTs and/or LRAs, by targeting additional markers of tissue reservoirs or infected cell types, or by serving as targeting moieties in engineered cell therapy. Finally, various combinations of the described bNAb applications may play a role in the development of a true "cure" for HIV to eradicate HIV entirely, although the risk of eliminating certain reservoir tissue cells may encourage the use of alternative strategies to eliminate viral DNA from latent cells without eradicating the cells. In conclusion, bNAbs are potent and promising agents for HIV prevention and treatment at various stages of infection. Their sole use as therapy faces challenges of viral evasion, immunogenicity, and reservoir latency, which can be combatted by employing various, often complementary strategies in combination with each other and/or existing ART regimens. While the clinical use of HIV Abs has never been closer, remaining studies to precisely define, model, and understand the complex roles and dynamics of HIV Abs and viral evolution in the context of the human immune system and anatomical compartmentalization will be critical to optimizing their clinical safety and efficacy.

\section{AUTHOR CONTRIBUTIONS}

$\mathrm{CH}$ wrote and MA reviewed this article.

\section{FUNDING}

The authors are supported by NIAID NIH 1R01AI102691 (MA), NIAID and NIGMS 1R01AI131975 (MA), and NIAID 5F30 AI122970 $(\mathrm{CH})$, and the Bill and Melinda Gates Foundation OPP1114729 and OPP1146996 (MA). 


\section{REFERENCES}

1. Stamatatos L, Morris L, Burton DR, Mascola JR. Neutralizing antibodies generated during natural HIV-1 infection: good news for an HIV-1 vaccine? Nat Med (2009) 15(8):866-70. doi:10.1038/nm.1949

2. Euler Z, van Gils MJ, Bunnik EM, Phung P, Schweighardt B, Wrin T, et al. Cross-reactive neutralizing humoral immunity does not protect from HIV type 1 disease progression. J Infect Dis (2010) 201(7):1045-53. doi:10.1086/651144

3. Horwitz JA, Halper-Stromberg A, Mouquet H, Gitlin AD, Tretiakova A, Eisenreich TR, et al. HIV-1 suppression and durable control by combining single broadly neutralizing antibodies and antiretroviral drugs in humanized mice. Proc Natl Acad Sci U S A (2013) 110(41):16538-43. doi:10.1073/ pnas. 1315295110

4. Balazs AB, Chen J, Hong CM, Rao DS, Yang L, Baltimore D. Antibody-based protection against HIV infection by vectored immunoprophylaxis. Nature (2011) 481(7379):81-4. doi:10.1038/nature10660

5. Gauduin MC, Parren PW, Weir R, Barbas CF, Burton DR, Koup RA. Passive immunization with a human monoclonal antibody protects huPBL-SCID mice against challenge by primary isolates of HIV-1. Nat Med (1997) 3(12):1389-93. doi:10.1038/nm1297-1389

6. Parren PW, Ditzel HJ, Gulizia RJ, Binley JM, Barbas CF 3rd, Burton DR, et al. Protection against HIV-1 infection in hu-PBL-SCID mice by passive immunization with a neutralizing human monoclonal antibody against the gp120 CD4-binding site. AIDS (1995) 9(6):F1-6. doi:10.1097/00002030199506000-00001

7. Veselinovic M, Neff CP, Mulder LR, Akkina R. Topical gel formulation of broadly neutralizing anti-HIV-1 monoclonal antibody VRC01 confers protection against HIV-1 vaginal challenge in a humanized mouse model. Virology (2012) 432(2):505-10. doi:10.1016/j.virol.2012.06.025

8. Shingai M, Donau OK, Plishka RJ, Buckler-White A, Mascola JR, Nabel GJ, et al. Passive transfer of modest titers of potent and broadly neutralizing anti-HIV monoclonal antibodies block SHIV infection in macaques. J Exp Med (2014) 211(10):2061-74. doi:10.1084/jem.20132494

9. Hessell AJ, Rakasz EG, Tehrani DM, Huber M, Weisgrau KL, Landucci G, et al. Broadly neutralizing monoclonal antibodies 2F5 and 4E10 directed against the human immunodeficiency virus type $1 \mathrm{gp} 41$ membrane-proximal external region protect against mucosal challenge by simian-human immunodeficiency virus SHIVBa-L. J Virol (2010) 84(3):1302-13. doi:10.1128/ JVI.01272-09

10. Hessell AJ, Poignard P, Hunter M, Hangartner L, Tehrani DM, Bleeker WK, et al. Effective, low-titer antibody protection against low-dose repeated mucosal SHIV challenge in macaques. Nat Med (2009) 15(8):951-4. doi:10.1038/ nm.1974

11. Hessell AJ, Rakasz EG, Poignard P, Hangartner L, Landucci G, Forthal DN, et al. Broadly neutralizing human anti-HIV antibody 2 G12 is effective in protection against mucosal SHIV challenge even at low serum neutralizing titers. PLoS Pathog (2009) 5(5):e1000433. doi:10.1371/journal.ppat. 1000433

12. Mascola JR, Stiegler G, VanCott TC, Katinger H, Carpenter CB, Hanson CE, et al. Protection of macaques against vaginal transmission of a pathogenic HIV-1/SIV chimeric virus by passive infusion of neutralizing antibodies. Nat Med (2000) 6(2):207-10. doi:10.1038/72318

13. Barouch DH, Whitney JB, Moldt B, Klein F, Oliveira TY, Liu J, et al. Therapeutic efficacy of potent neutralizing HIV-1-specific monoclonal antibodies in SHIV-infected rhesus monkeys. Nature (2013) 503(7475):224-8. doi:10.1038/nature 12744

14. Bar KJ, Sneller MC, Harrison LJ, Justement JS, Overton ET, Petrone ME, et al. Effect of HIV antibody VRC01 on viral rebound after treatment interruption. NEngl J Med (2016) 375(21):2037-50. doi:10.1056/NEJMoa1608243

15. Caskey M, Klein F, Lorenzi JC, Seaman MS, West AP Jr, Buckley N, et al. Viraemia suppressed in HIV-1-infected humans by broadly neutralizing antibody 3BNC117. Nature (2015) 522(7557):487-91. doi:10.1038/ nature 14411

16. Caskey M, Schoofs T, Gruell H, Settler A, Karagounis T, Kreider EF, et al. Antibody 10-1074 suppresses viremia in HIV-1-infected individuals. Nat Med (2017) 23(2):185-91. doi:10.1038/nm.4268

17. Lynch RM, Boritz E, Coates EE, DeZure A, Madden P, Costner P, et al. Virologic effects of broadly neutralizing antibody VRC01 administration during chronic HIV-1 infection. Sci Transl Med (2015) 7(319):319ra206. doi:10.1126/scitranslmed.aad5752

18. Scheid JF, Horwitz JA, Bar-On Y, Kreider EF, Lu CL, Lorenzi JC, et al. HIV-1 antibody 3BNC117 suppresses viral rebound in humans during treatment interruption. Nature (2016) 535(7613):556-60. doi:10.1038/ nature 18929

19. Schoofs T, Klein F, Braunschweig M, Kreider EF, Feldmann A, Nogueira L, et al. HIV-1 therapy with monoclonal antibody 3BNC117 elicits host immune responses against HIV-1. Science (2016) 352(6288):997-1001. doi:10.1126/ science.aaf0972

20. Bhiman JN, Lynch RM. Broadly neutralizing antibodies as treatment: effects on virus and immune system. Curr HIV/AIDS Rep (2017) 14(2):54-62. doi:10.1007/s11904-017-0352-1

21. Caskey M, Klein F, Nussenzweig MC. Broadly neutralizing antibodies for HIV-1 prevention or immunotherapy. N Engl J Med (2016) 375(21):2019-21. doi:10.1056/NEJMp1613362

22. Ferrari G, Haynes BF, Koenig S, Nordstrom JL, Margolis DM, Tomaras GD. Envelope-specific antibodies and antibody-derived molecules for treating and curing HIV infection. Nat Rev Drug Discov (2016) 15(12):823-34. doi: $10.1038 /$ nrd.2016.173

23. Julg B, Alter G. Broadly neutralizing antibodies: magic bullets against HIV? Immunity (2016) 44(6):1253-4. doi:10.1016/j.immuni.2016.06.012

24. Stephenson KE, Barouch DH. Broadly neutralizing antibodies for HIV eradication. Curr HIV/AIDS Rep (2016) 13(1):31-7. doi:10.1007/ s11904-016-0299-7

25. Halper-Stromberg A, Nussenzweig MC. Towards HIV-1 remission: potential roles for broadly neutralizing antibodies. JClin Invest (2016) 126(2):415-23. doi:10.1172/JCI80561

26. Zhang Z, Li S, Gu Y, Xia N. Antiviral therapy by HIV-1 broadly neutralizing and inhibitory antibodies. Int J Mol Sci (2016) 17(11):1901. doi:10.3390/ ijms17111901

27. Yaseen MM, Yaseen MM, Alqudah MA. Broadly neutralizing antibodies: an approach to control HIV-1 infection. Int Rev Immunol (2017) 36(1):31-40. doi:10.1080/08830185.2016.1225301

28. Hua CK, Ackerman ME. Engineering broadly neutralizing antibodies for HIV prevention and therapy. Adv Drug Deliv Rev (2016) 103:157-73. doi:10.1016/j.addr.2016.01.013

29. Gautam R, Nishimura Y, Pegu A, Nason MC, Klein F, Gazumyan A, et al. A single injection of anti-HIV-1 antibodies protects against repeated SHIV challenges. Nature (2016) 533(7601):105-9. doi:10.1038/nature17677

30. Deruaz M, Moldt B, Le KM, Power KA, Vrbanac VD, Tanno S, et al. Protection of humanized mice from repeated intravaginal HIV challenge by passive immunization: a model for studying the efficacy of neutralizing antibodies in vivo. J Infect Dis (2016) 214(4):612-6. doi:10.1093/infdis/ jiw203

31. Ledgerwood JE, Coates EE, Yamshchikov G, Saunders JG, Holman L, Enama ME, et al. Safety, pharmacokinetics and neutralization of the broadly neutralizing HIV-1 human monoclonal antibody VRC01 in healthy adults. Clin Exp Immunol (2015) 182(3):289-301. doi:10.1111/cei. 12692

32. Lu CL, Murakowski DK, Bournazos S, Schoofs T, Sarkar D, HalperStromberg A, et al. Enhanced clearance of HIV-1-infected cells by broadly neutralizing antibodies against HIV-1 in vivo. Science (2016) 352(6288): 1001-4. doi:10.1126/science.aaf1279

33. Webb NE, Montefiori DC, Lee B. Dose-response curve slope helps predict therapeutic potency and breadth of HIV broadly neutralizing antibodies. Nat Commun (2015) 6:8443. doi:10.1038/ncomms9443

34. Haigwood NL, Montefiori DC, Sutton WF, McClure J, Watson AJ, Voss G, et al. Passive immunotherapy in simian immunodeficiency virus-infected macaques accelerates the development of neutralizing antibodies. J Virol (2004) 78(11):5983-95. doi:10.1128/JVI.78.11.5983-5995.2004

35. Ng CT, Jaworski JP, Jayaraman P, Sutton WF, Delio P, Kuller L, et al. Passive neutralizing antibody controls SHIV viremia and enhances B cell responses in infant macaques. Nat Med (2010) 16(10):1117-9. doi:10.1038/ nm.2233

36. Klein F, Diskin R, Scheid JF, Gaebler C, Mouquet H, Georgiev IS, et al. Somatic mutations of the immunoglobulin framework are generally required for broad and potent HIV-1 neutralization. Cell (2013) 153(1):126-38 doi:10.1016/j.cell.2013.03.018 
37. Pelegrin M, Naranjo-Gomez M, Piechaczyk M. Antiviral monoclonal antibodies: can they be more than simple neutralizing agents? Trends Microbiol (2015) 23(10):653-65. doi:10.1016/j.tim.2015.07.005

38. Graham BS, Ambrosino DM. History of passive antibody administration for prevention and treatment of infectious diseases. Curr Opin HIV AIDS (2015) 10(3):129-34. doi:10.1097/COH.0000000000000154

39. Parren PW, Marx PA, Hessell AJ, Luckay A, Harouse J, Cheng-Mayer C, et al. Antibody protects macaques against vaginal challenge with a pathogenic R5 simian/human immunodeficiency virus at serum levels giving complete neutralization in vitro. J Virol (2001) 75(17):8340-7. doi:10.1128/ JVI.75.17.8340-8347.2001

40. Hessell AJ, Hangartner L, Hunter M, Havenith CE, Beurskens FJ, Bakker JM, et al. Fc receptor but not complement binding is important in antibody protection against HIV. Nature (2007) 449(7158):101-4. doi:10.1038/ nature 06106

41. Moldt B, Rakasz EG, Schultz N, Chan-Hui PY, Swiderek K, Weisgrau KL, et al. Highly potent HIV-specific antibody neutralization in vitro translates into effective protection against mucosal SHIV challenge in vivo. Proc Natl Acad Sci U S A (2012) 109(46):18921-5. doi:10.1073/pnas.1214785109

42. Shingai M, Nishimura Y, Klein F, Mouquet H, Donau OK, Plishka R, et al. Antibody-mediated immunotherapy of macaques chronically infected with SHIV suppresses viraemia. Nature (2013) 503(7475):277-80. doi:10.1038/ nature 12746

43. Lewis GK, Pazgier M, DeVico AL. Survivors remorse: antibody-mediated protection against HIV-1. Immunol Rev (2017) 275(1):271-84. doi:10.1111/ imr. 12510

44. Horwitz JA, Bar-On Y, Lu CL, Fera D, Lockhart AAK, Lorenzi JCC, et al. Non-neutralizing antibodies alter the course of HIV-1 infection in vivo. Cell (2017) 170(4):637-48.e10. doi:10.1016/j.cell.2017.06.048

45. Xu JY, Gorny MK, Palker T, Karwowska S, Zolla-Pazner S. Epitope mapping of two immunodominant domains of gp41, the transmembrane protein of human immunodeficiency virus type 1 , using ten human monoclonal antibodies. J Virol (1991) 65(9):4832-8.

46. Santra S, Tomaras GD, Warrier R, Nicely NI, Liao HX, Pollara J, et al. Human non-neutralizing HIV-1 envelope monoclonal antibodies limit the number of founder viruses during SHIV mucosal infection in rhesus macaques. PLoS Pathog (2015) 11(8):e1005042. doi:10.1371/journal. ppat. 1005042

47. Moog C, Dereuddre-Bosquet N, Teillaud JL, Biedma ME, Holl V, Van Ham G, et al. Protective effect of vaginal application of neutralizing and nonneutralizing inhibitory antibodies against vaginal SHIV challenge in macaques. Mucosal Immunol (2014) 7(1):46-56. doi:10.1038/mi.2013.23

48. Burton DR, Hessell AJ, Keele BF, Klasse PJ, Ketas TA, Moldt B, et al. Limited or no protection by weakly or nonneutralizing antibodies against vaginal SHIV challenge of macaques compared with a strongly neutralizing antibody. Proc Natl Acad Sci U S A (2011) 108(27):11181-6. doi:10.1073/pnas. 1103012108

49. Douglas AO, Martinez DR, Permar SR. The role of maternal HIV envelope-specific antibodies and mother-to-child transmission risk. Front Immunol (2017) 8:1091. doi:10.3389/fimmu.2017.01091

50. Haynes BF, Gilbert PB, McElrath MJ, Zolla-Pazner S, Tomaras GD, Alam SM, et al. Immune-correlates analysis of an HIV-1 vaccine efficacy trial. $N$ Engl J Med (2012) 366(14):1275-86. doi:10.1056/NEJMoa1113425

51. Zolla-Pazner S, deCamp A, Gilbert PB, Williams C, Yates NL, Williams WT, et al. Vaccine-induced IgG antibodies to V1V2 regions of multiple HIV-1 subtypes correlate with decreased risk of HIV-1 infection. PLoS One (2014) 9(2):e87572. doi:10.1371/journal.pone.0087572

52. Seaman MS, Janes H, Hawkins N, Grandpre LE, Devoy C, Giri A, et al. Tiered categorization of a diverse panel of HIV-1 Env pseudoviruses for assessment of neutralizing antibodies. J Virol (2010) 84(3):1439-52. doi:10.1128/ JVI.02108-09

53. Wibmer CK, Moore PL, Morris L. HIV broadly neutralizing antibody targets. Curr Opin HIV AIDS (2015) 10(3):135-43. doi:10.1097/COH. 0000000000000153

54. Georgiev IS, Gordon Joyce M, Zhou T, Kwong PD. Elicitation of HIV-1neutralizing antibodies against the CD4-binding site. Curr Opin HIV AIDS (2013) 8(5):382-92. doi:10.1097/COH.0b013e328363a90e

55. Huang J, Kang BH, Ishida E, Zhou T, Griesman T, Sheng Z, et al. Identification of a CD4-binding-site antibody to HIV that evolved near-pan neutralization breadth. Immunity (2016) 45(5):1108-21. doi:10.1016/j. immuni.2016.10.027

56. Kong R, Xu K, Zhou T, Acharya P, Lemmin T, Liu K, et al. Fusion peptide of HIV-1 as a site of vulnerability to neutralizing antibody. Science (2016) 352(6287):828-33. doi:10.1126/science.aae0474

57. Julg B, Tartaglia LJ, Keele BF, Wagh K, Pegu A, Sok D, et al. Broadly neutralizing antibodies targeting the HIV-1 envelope V2 apex confer protection against a clade C SHIV challenge. Sci Transl Med (2017) 9:406. doi:10.1126/ scitranslmed.aal1321

58. Freund NT, Wang H, Scharf L, Nogueira L, Horwitz JA, Bar-On Y, et al. Coexistence of potent HIV-1 broadly neutralizing antibodies and antibodysensitive viruses in a viremic controller. Sci Transl Med (2017) 9:373. doi:10.1126/ scitranslmed.aal2144

59. Wagh K, Bhattacharya T, Williamson C, Robles A, Bayne M, Garrity J, et al. Optimal combinations of broadly neutralizing antibodies for prevention and treatment of HIV-1 clade C infection. PLoS Pathog (2016) 12(3): e1005520. doi:10.1371/journal.ppat.1005520

60. Kong R, Louder MK, Wagh K, Bailer RT, deCamp A, Greene K, et al. Improving neutralization potency and breadth by combining broadly reactive HIV-1 antibodies targeting major neutralization epitopes. J Virol (2015) 89(5):2659-71. doi:10.1128/JVI.03136-14

61. Klein F, Halper-Stromberg A, Horwitz JA, Gruell H, Scheid JF, Bournazos S, et al. HIV therapy by a combination of broadly neutralizing antibodies in humanized mice. Nature (2012) 492(7427):118-22. doi:10.1038/ nature11604

62. Bournazos S, Gazumyan A, Seaman MS, Nussenzweig MC, Ravetch JV. Bispecific anti-HIV-1 antibodies with enhanced breadth and potency. Cell (2016) 165(7):1609-20. doi:10.1016/j.cell.2016.04.050

63. Huang Y, Yu J, Lanzi A, Yao X, Andrews CD, Tsai L, et al. Engineered bispecific antibodies with exquisite HIV-1-neutralizing activity. Cell (2016) 165(7):1621-31. doi:10.1016/j.cell.2016.05.024

64. Xu L, Pegu A, Rao E, Doria-Rose N, Beninga J, McKee $\mathrm{K}$, et al. Trispecific broadly neutralizing HIV antibodies mediate potent SHIV protection in macaques. Science (2017) 358(6359):85-90. doi:10.1126/science. aan 8630

65. Galimidi RP, Klein JS, Politzer MS, Bai S, Seaman MS, Nussenzweig MC, et al. Intra-spike crosslinking overcomes antibody evasion by HIV-1. Cell (2015) 160(3):433-46. doi:10.1016/j.cell.2015.01.016

66. World Health Organization. HIV Drug Resistance Report 2017. Geneva: World Health Organization (2017). Licence: CC BY-NC-SA 3.0 IGO.

67. Lynch RM, Wong P, Tran L, O’Dell S, Nason MC, Li Y, et al. HIV-1 fitness cost associated with escape from the VRC01 class of CD4 binding site neutralizing antibodies. J Virol (2015) 89(8):4201-13. doi:10.1128/JVI. 03608-14

68. Sather DN, Carbonetti S, Kehayia J, Kraft Z, Mikell I, Scheid JF, et al. Broadly neutralizing antibodies developed by an HIV-positive elite neutralizer exact a replication fitness cost on the contemporaneous virus. J Virol (2012) 86(23):12676-85. doi:10.1128/JVI.01893-12

69. Diskin R, Klein F, Horwitz JA, Halper-Stromberg A, Sather DN, Marcovecchio PM, et al. Restricting HIV-1 pathways for escape using rationally designed anti-HIV-1 antibodies. J Exp Med (2013) 210(6):1235-49. doi:10.1084/jem.20130221

70. Bar KJ, Tsao CY, Iyer SS, Decker JM, Yang Y, Bonsignori M, et al. Early low-titer neutralizing antibodies impede HIV-1 replication and select for virus escape. PLoS Pathog (2012) 8(5):e1002721. doi:10.1371/journal.ppat. 1002721

71. van Gils MJ, Bunnik EM, Burger JA, Jacob Y, Schweighardt B, Wrin T, et al. Rapid escape from preserved cross-reactive neutralizing humoral immunity without loss of viral fitness in HIV-1-infected progressors and long-term nonprogressors. J Virol (2010) 84(7):3576-85. doi:10.1128/JVI. 02622-09

72. Boesch AW, Alter G, Ackerman ME. Prospects for engineering HIV-specific antibodies for enhanced effector function and half-life. Curr Opin HIV AIDS (2015) 10(3):160-9. doi:10.1097/COH.0000000000000149

73. Saunders KO, Pegu A, Georgiev IS, Zeng M, Joyce MG, Yang ZY, et al. Sustained delivery of a broadly neutralizing antibody in nonhuman primates confers long-term protection against simian/human immunodeficiency virus infection. J Virol (2015) 89(11):5895-903. doi:10.1128/JVI. 00210-15 
74. Ko SY, Pegu A, Rudicell RS, Yang ZY, Joyce MG, Chen X, et al. Enhanced neonatal Fc receptor function improves protection against primate SHIV infection. Nature (2014) 514(7524):642-5. doi:10.1038/nature13612

75. Fuchs SP, Desrosiers RC. Promise and problems associated with the use of recombinant AAV for the delivery of anti-HIV antibodies. Mol Ther Methods Clin Dev (2016) 3:16068. doi:10.1038/mtm.2016.68

76. Ye GJ, Budzynski E, Sonnentag P, Nork TM, Miller PE, Sharma AK, et al. Safety and biodistribution evaluation in cynomolgus macaques of rAAV2tYFPR1.7-hCNGB3, a recombinant AAV vector for treatment of achromatopsia. Hum Gene Ther Clin Dev (2016). doi:10.1089/humc.2015.163

77. Mancuso K, Hauswirth WW, Li Q, Connor TB, Kuchenbecker JA, Mauck MC, et al. Gene therapy for red-green colour blindness in adult primates. Nature (2009) 461(7265):784-7. doi:10.1038/nature08401

78. Nathwani AC, Gray JT, McIntosh J, Ng CY, Zhou J, Spence Y, et al. Safe and efficient transduction of the liver after peripheral vein infusion of self-complementary AAV vector results in stable therapeutic expression of human FIX in nonhuman primates. Blood (2007) 109(4):1414-21. doi:10.1182/blood-2006-03-010181

79. Rivera VM, Gao GP, Grant RL, Schnell MA, Zoltick PW, Rozamus LW, et al. Long-term pharmacologically regulated expression of erythropoietin in primates following AAV-mediated gene transfer. Blood (2005) 105(4): 1424-30. doi:10.1182/blood-2004-06-2501

80. Nathwani AC, Tuddenham EG, Rangarajan S, Rosales C, McIntosh J, Linch DC, et al. Adenovirus-associated virus vector-mediated gene transfer in hemophilia B. N Engl J Med (2011) 365(25):2357-65. doi:10.1056/ NEJMoa1108046

81. Nathwani AC, Reiss UM, Tuddenham EG, Rosales C, Chowdary P, McIntosh J, et al. Long-term safety and efficacy of factor IX gene therapy in hemophilia B. N Engl J Med (2014) 371(21):1994-2004. doi:10.1056/ NEJMoa1407309

82. Stroes ES1, Nierman MC, Meulenberg JJ, Franssen R, Twisk J, Henny CP, et al. Intramuscular administration of AAV1-lipoprotein lipase S447X lowers triglycerides in lipoprotein lipase-deficient patients. Arterioscler Thromb Vasc Biol (2008) 28(12):2303-4. doi:10.1161/ATVBAHA. 108.175620

83. Gaudet D, Méthot J, Déry S, Brisson D, Essiembre C, Tremblay G, et al. Efficacy and long-term safety of alipogene tiparvovec (AAV1-LPLS447X) gene therapy for lipoprotein lipase deficiency: an open-label trial. Gene Ther (2013) 20(4):361-9. doi:10.1038/gt.2012.43

84. Flotte TR, Trapnell BC, Humphries M, Carey B, Calcedo R, Rouhani $F$, et al. Phase 2 clinical trial of a recombinant adeno-associated viral vector expressing alphal-antitrypsin: interim results. Hum Gene Ther (2011) 22(10):1239-47. doi:10.1089/hum.2011.053

85. Brantly ML, Chulay JD, Wang L, Mueller C, Humphries M, Spencer LT, et al. Sustained transgene expression despite $\mathrm{T}$ lymphocyte responses in a clinical trial of rAAV1-AAT gene therapy. Proc Natl Acad Sci U S A (2009) 106(38):16363-8. doi:10.1073/pnas.0904514106

86. Yla-Herttuala S. Endgame: glybera finally recommended for approval as the first gene therapy drug in the European union. Mol Ther (2012) 20(10):1831-2. doi:10.1038/mt.2012.194

87. Scott LJ. Alipogene tiparvovec: a review of its use in adults with familial lipoprotein lipase deficiency. Drugs (2015) 75(2):175-82. doi:10.1007/s40265014-0339-9

88. Johnson PR, Schnepp BC, Zhang J, Connell MJ, Greene SM, Yuste E, et al. Vector-mediated gene transfer engenders long-lived neutralizing activity and protection against SIV infection in monkeys. Nat Med (2009) 15(8):901-6. doi:10.1038/nm.1967

89. Gardner MR, Kattenhorn LM, Kondur HR, von Schaewen M, Dorfman T, Chiang JJ, et al. AAV-expressed eCD4-Ig provides durable protection from multiple SHIV challenges. Nature (2015) 519(7541):87-91. doi:10.1038/ nature 14264

90. Fuchs SP, Martinez-Navio JM, Piatak M Jr, Lifson JD, Gao G, Desrosiers RC. AAV-delivered antibody mediates significant protective effects against SIVmac239 challenge in the absence of neutralizing activity. PLoS Pathog (2015) 11(8):e1005090. doi:10.1371/journal.ppat.1005090

91. Balazs AB, Ouyang Y, Hong CM, Chen J, Nguyen SM, Rao DS, et al. Vectored immunoprophylaxis protects humanized mice from mucosal HIV transmission. Nat Med (2014) 20(3):296-300. doi:10.1038/nm.3471
92. Martinez-Navio JM, Fuchs SP, Pedreño-López S, Rakasz EG, Gao G, Desrosiers RC. Host anti-antibody responses following adeno-associated virus-mediated delivery of antibodies against HIV and SIV in rhesus monkeys. Mol Ther (2016) 24(1):76-86. doi:10.1038/mt.2015.191

93. Basner-Tschakarjan E, Mingozzi F. Cell-mediated immunity to AAV vectors, evolving concepts and potential solutions. Front Immunol (2014) 5:350. doi:10.3389/fimmu.2014.00350

94. Rogers GL, Martino AT, Aslanidi GV, Jayandharan GR, Srivastava A, Herzog RW. Innate immune responses to AAV vectors. Front Microbiol (2011) 2:194. doi:10.3389/fmicb.2011.00194

95. Hollevoet K, Declerck PJ. State of play and clinical prospects of antibody gene transfer. J Transl Med (2017) 15(1):131. doi:10.1186/s12967-0171234-4

96. Jardine JG, Ota T, Sok D, Pauthner M, Kulp DW, Kalyuzhniy O, et al. HIV-1 vaccines. Priming a broadly neutralizing antibody response to HIV-1 using a germline-targeting immunogen. Science (2015) 349(6244):156-61. doi:10.1126/science.aac5894

97. McGuire AT, Gray MD, Dosenovic P, Gitlin AD, Freund NT, Petersen J, et al. Specifically modified Env immunogens activate B-cell precursors of broadly neutralizing HIV-1 antibodies in transgenic mice. Nat Commun (2016) 7:10618. doi:10.1038/ncomms10618

98. Briney B, Sok D, Jardine JG, Kulp DW, Skog P, Menis S, et al. Tailored immunogens direct affinity maturation toward HIV neutralizing antibodies. Cell (2016) 166(6):1459-70.e11. doi:10.1016/j.cell.2016.08.005

99. Liu J, Ghneim K, Sok D, Bosche WJ, Li Y, Chipriano E, et al. Antibody-mediated protection against SHIV challenge includes systemic clearance of distal virus. Science (2016) 353(6303):1045-9. doi:10.1126/science. aag0491

100. Shen R, Drelichman ER, Bimczok D, Ochsenbauer C, Kappes JC, Cannon JA, et al. GP41-specific antibody blocks cell-free HIV type 1 transcytosis through human rectal mucosa and model colonic epithelium. J Immunol (2010) 184(7):3648-55. doi:10.4049/jimmunol.0903346

101. Watkins JD, Sholukh AM, Mukhtar MM, Siddappa NB, Lakhashe SK, Kim M, et al. Anti-HIV IgA isotypes: differential virion capture and inhibition of transcytosis are linked to prevention of mucosal R5 SHIV transmission. AIDS (2013) 27(9):F13-20. doi:10.1097/QAD.0b013e328360eac6

102. Wolbank S, Kunert R, Stiegler G, Katinger H. Characterization of human class-switched polymeric (immunoglobulin $\mathrm{M}[\operatorname{IgM}]$ and $\operatorname{IgA}$ ) anti-human immunodeficiency virus type 1 antibodies 2F5 and 2G12. J Virol (2003) 77(7): 4095-103. doi:10.1128/JVI.77.7.4095-4103.2003

103. Tudor D, Yu H, Maupetit J, Drillet AS, Bouceba T, Schwartz-Cornil I, et al. Isotype modulates epitope specificity, affinity, and antiviral activities of anti-HIV-1 human broadly neutralizing 2F5 antibody. Proc Natl Acad Sci U S A (2012) 109(31):12680-5. doi:10.1073/pnas.1200024109

104. Mouquet H, Scharf L, Euler Z, Liu Y, Eden C, Scheid JF, et al. Complex-type $\mathrm{N}$-glycan recognition by potent broadly neutralizing HIV antibodies. Proc Natl Acad Sci U S A (2012) 109(47):E3268-77. doi:10.1073/pnas.1217207109

105. Lorin V, Malbec M, Eden C, Bruel T, Porrot F, Seaman MS, et al. Broadly neutralizing antibodies suppress post-transcytosis HIV-1 infectivity. Mucosal Immunol (2017) 10(3):814-26. doi:10.1038/mi.2016.106

106. Robinson WE Jr, Montefiori DC, Mitchell WM, Prince AM, Alter HJ, Dreesman GR, et al. Antibody-dependent enhancement of human immunodeficiency virus type 1 (HIV-1) infection in vitro by serum from HIV-1infected and passively immunized chimpanzees. Proc Natl Acad Sci U S A (1989) 86(12):4710-4. doi:10.1073/pnas.86.12.4710

107. Robinson WE Jr, Kawamura T, Lake D, Masuho Y, Mitchell WM, Hersh EM. Antibodies to the primary immunodominant domain of human immunodeficiency virus type 1 (HIV-1) glycoprotein gp41 enhance HIV-1 infection in vitro. J Virol (1990) 64(11):5301-5.

108. Willey S, Aasa-Chapman MM, O'Farrell S, Pellegrino P, Williams I, Weiss RA, et al. Extensive complement-dependent enhancement of HIV-1 by autologous non-neutralising antibodies at early stages of infection. Retrovirology (2011) 8:16. doi:10.1186/1742-4690-8-16

109. Takeda A, Ennis FA. FcR-mediated enhancement of HIV-1 infection by antibody. AIDS Res Hum Retroviruses (1990) 6(8):999-1004.

110. Homsy J, Meyer M, Tateno M, Clarkson S, Levy JA. The Fc and not CD4 receptor mediates antibody enhancement of HIV infection in human cells. Science (1989) 244(4910):1357-60. doi:10.1126/science.2786647 
111. Laurence J, Saunders A, Early E, Salmon JE. Human immunodeficiency virus infection of monocytes: relationship to Fc-gamma receptors and antibody-dependent viral enhancement. Immunology (1990) 70(3):338-43.

112. Trischmann H, Davis D, Lachmann PJ. Lymphocytotropic strains of HIV type 1 when complexed with enhancing antibodies can infect macrophages via Fc gamma RIII, independently of CD4. AIDS Res Hum Retroviruses (1995) 11(3):343-52. doi:10.1089/aid.1995.11.343

113. Schutten M, Andeweg AC, Bosch ML, Osterhaus AD. Enhancement of infectivity of a non-syncytium inducing HIV-1 by $\mathrm{sCD} 4$ and by human antibodies that neutralize syncytium inducing HIV-1. Scand J Immunol (1995) 41(1):18-22. doi:10.1111/j.1365-3083.1995.tb03528.x

114. Guillon C, Schutten M, Boers PH, Gruters RA, Osterhaus AD. Antibodymediated enhancement of human immunodeficiency virus type 1 infectivity is determined by the structure of gp120 and depends on modulation of the gp120-CCR5 interaction. J Virol (2002) 76(6):2827-34. doi:10.1128/ JVI.76.6.2827-2834.2002

115. Gorlani A, Forthal DN. Antibody-dependent enhancement and the risk of HIV infection. Curr HIV Res (2013) 11(5):421-6. doi:10.2174/15701 $62 X 113116660062$

116. Takada A, Kawaoka Y. Antibody-dependent enhancement of viral infection: molecular mechanisms and in vivo implications. Rev Med Virol (2003) 13(6):387-98. doi:10.1002/rmv.405

117. Tóth FD, Szabó B, Ujhelyi E, Pálóczi K, Horváth A, Füst G, et al. Neutralizing and complement-dependent enhancing antibodies in different stages of HIV infection. AIDS (1991) 5(3):263-8. doi:10.1097/00002030199103000-00003

118. Füst G, Tóth FD, Kiss J, Ujhelyi E, Nagy I, Bánhegyi D. Neutralizing and enhancing antibodies measured in complement-restored serum samples from HIV-1-infected individuals correlate with immunosuppression and disease. AIDS (1994) 8(5):603-9. doi:10.1097/00002030-19940500000005

119. Montefiori DC, Pantaleo G, Fink LM, Zhou JT, Zhou JY, Bilska M, et al. Neutralizing and infection-enhancing antibody responses to human immunodeficiency virus type 1 in long-term nonprogressors. J Infect Dis (1996) 173(1):60-7. doi:10.1093/infdis/173.1.60

120. Gilbert PB, Peterson ML, Follmann D, Hudgens MG, Francis DP, Gurwith M, et al. Correlation between immunologic responses to a recombinant glycoprotein 120 vaccine and incidence of HIV- 1 infection in a phase 3 HIV-1 preventive vaccine trial. J Infect Dis (2005) 191(5):666-77. doi:10.1086/428405

121. Forthal DN, Gilbert PB, Landucci G, Phan T. Recombinant gp120 vaccine-induced antibodies inhibit clinical strains of HIV-1 in the presence of Fc receptor-bearing effector cells and correlate inversely with HIV infection rate. J Immunol (2007) 178(10):6596-603. doi:10.4049/jimmunol.178. 10.6596

122. Brouwer KC, Lal RB, Mirel LB, Yang C, van Eijk AM, Ayisi J, et al. Polymorphism of Fc receptor IIa for IgG in infants is associated with susceptibility to perinatal HIV-1 infection. AIDS (2004) 18(8):1187-94. doi:10.1097/ 00002030-200405210-00012

123. Ananworanich J, McSteen B, Robb ML. Broadly neutralizing antibody and the HIV reservoir in acute HIV infection: a strategy toward HIV remission? Curr Opin HIV AIDS (2015) 10(3):198-206. doi:10.1097/COH.0000000000000144

124. Lewis GK. The first $24 \mathrm{~h}$ : targeting the window of opportunity for antibody-mediated protection against HIV-1 transmission. Curr Opin HIV AIDS (2016) 11(6):561-8. doi:10.1097/COH.0000000000000319

125. Gómez-Román VR, Patterson LJ, Venzon D, Liewehr D, Aldrich K, Florese R, et al. Vaccine-elicited antibodies mediate antibody-dependent cellular cytotoxicity correlated with significantly reduced acute viremia in rhesus macaques challenged with SIVmac251. J Immunol (2005) 174(4):2185-9. doi:10.4049/jimmunol.174.4.2185

126. Bolton DL, Pegu A, Wang K, McGinnis K, Nason M, Foulds K, et al. Human immunodeficiency virus type 1 monoclonal antibodies suppress acute simian-human immunodeficiency virus viremia and limit seeding of cell-associated viral reservoirs. J Virol (2015) 90(3):1321-32. doi:10.1128/ JVI.02454-15

127. Ferrantelli F, Buckley KA, Rasmussen RA, Chalmers A, Wang T, Li PL, et al. Time dependence of protective post-exposure prophylaxis with human monoclonal antibodies against pathogenic SHIV challenge in newborn macaques. Virology (2007) 358(1):69-78. doi:10.1016/j.virol.2006.07.056
128. Nishimura $\mathrm{Y}$, Igarashi T, Haigwood NL, Sadjadpour R, Donau OK, Buckler C, et al. Transfer of neutralizing IgG to macaques $6 \mathrm{~h}$ but not $24 \mathrm{~h}$ after SHIV infection confers sterilizing protection: implications for HIV-1 vaccine development. Proc Natl Acad Sci U S A (2003) 100(25):15131-6. doi:10.1073/pnas.2436476100

129. Barouch DH, Ghneim K, Bosche WJ, Li Y, Berkemeier B, Hull M, et al. Rapid inflammasome activation following mucosal SIV infection of rhesus monkeys. Cell (2016) 165(3):656-67. doi:10.1016/j.cell.2016. 03.021

130. Cohen MS, et al. Acute HIV-1 infection. N Engl J Med (2011) 364(20): 1943-54. doi:10.1056/NEJMra1011874

131. Bournazos S, Klein F, Pietzsch J, Seaman MS, Nussenzweig MC, Ravetch JV. Broadly neutralizing anti-HIV-1 antibodies require Fc effector functions for in vivo activity. Cell (2014) 158(6):1243-53. doi:10.1016/j.cell.2014. 08.023

132. Halper-Stromberg A, Lu CL, Klein F, Horwitz JA, Bournazos S, Nogueira L, et al. Broadly neutralizing antibodies and viral inducers decrease rebound from HIV-1 latent reservoirs in humanized mice. Cell (2014) 158(5):989-99. doi:10.1016/j.cell.2014.07.043

133. Pollara J, Bonsignori M, Moody MA, Liu P, Alam SM, Hwang KK, et al. HIV-1 vaccine-induced $\mathrm{C} 1$ and V2 Env-specific antibodies synergize for increased antiviral activities. J Virol (2014) 88(14):7715-26. doi:10.1128/ JVI.00156-14

134. Forthal DN, Landucci G, Cole KS, Marthas M, Becerra JC, Van Rompay K. Rhesus macaque polyclonal and monoclonal antibodies inhibit simian immunodeficiency virus in the presence of human or autologous rhesus effector cells. J Virol (2006) 80(18):9217-25. doi:10.1128/JVI.02746-05

135. Fouts TR, Bagley K, Prado IJ, Bobb KL, Schwartz JA, Xu R, et al. Balance of cellular and humoral immunity determines the level of protection by HIV vaccines in rhesus macaque models of HIV infection. Proc Natl Acad Sci U S A (2015) 112(9):E992-9. doi:10.1073/pnas.1423669112

136. Lambour J, Naranjo-Gomez M, Piechaczyk M, Pelegrin M. Converting monoclonal antibody-based immunotherapies from passive to active: bringing immune complexes into play. Emerg Microbes Infect (2016) 5(8):e92. doi:10.1038/emi.2016.97

137. Posch W, Cardinaud S, Hamimi C, Fletcher A, Mühlbacher A, Loacker K, et al. Antibodies attenuate the capacity of dendritic cells to stimulate HIVspecific cytotoxic T lymphocytes. J Allergy Clin Immunol (2012) 130(6): 1368-74.e2. doi:10.1016/j.jaci.2012.08.025

138. Hioe CE, Visciano ML, Kumar R, Liu J, Mack EA, Simon RE, et al. The use of immune complex vaccines to enhance antibody responses against neutralizing epitopes on HIV-1 envelope gp120. Vaccine (2009) 28(2):352-60. doi:10.1016/j.vaccine.2009.10.040

139. Kumar R, Tuen M, Li H, Tse DB, Hioe CE. Improving immunogenicity of HIV-1 envelope gp120 by glycan removal and immune complex formation. Vaccine (2011) 29(48):9064-74. doi:10.1016/j.vaccine.2011.09.057

140. Kumar R, Tuen M, Liu J, Nàdas A, Pan R, Kong X, et al. Elicitation of broadly reactive antibodies against glycan-modulated neutralizing V3 epitopes of HIV-1 by immune complex vaccines. Vaccine (2013) 31(46):5413-21. doi:10.1016/j.vaccine.2013.09.010

141. Kumar R, Visciano ML, Li H, Hioe C. Targeting a neutralizing epitope of HIV envelope Gp120 by immune complex vaccine. J AIDS Clin Res (2012) S8(2). doi:10.4172/2155-6113.S8-002

142. Guo H, König R, Deng M, Riess M, Mo J, Zhang L, et al. NLRX1 sequesters STING to negatively regulate the interferon response, thereby facilitating the replication of HIV-1 and DNA viruses. Cell Host Microbe (2016) 19(4):515-28. doi:10.1016/j.chom.2016.03.001

143. Ji J, Cloyd MW. HIV-1 binding to CD4 on CD4+CD25+ regulatory T cells enhances their suppressive function and induces them to home to, and accumulate in, peripheral and mucosal lymphoid tissues: an additional mechanism of immunosuppression. Int Immunol (2009) 21(3):283-94. doi:10.1093/intimm/dxn146

144. Estes JD, Li Q, Reynolds MR, Wietgrefe S, Duan L, Schacker T, et al. Premature induction of an immunosuppressive regulatory $\mathrm{T}$ cell response during acute simian immunodeficiency virus infection. J Infect Dis (2006) 193(5):703-12. doi:10.1086/500368

145. D'Souza M, Fontenot AP, Mack DG, Lozupone C, Dillon S, Meditz A, et al. Programmed death 1 expression on HIV-specific CD4+ T cells is driven by 
viral replication and associated with T cell dysfunction. J Immunol (2007) 179(3):1979-87. doi:10.4049/jimmunol.179.3.1979

146. Estes JD, Gordon SN, Zeng M, Chahroudi AM, Dunham RM, Staprans SI, et al. Early resolution of acute immune activation and induction of PD-1 in SIV-infected sooty mangabeys distinguishes nonpathogenic from pathogenic infection in rhesus macaques. JImmunol (2008) 180(10):6798-807. doi:10.4049/jimmunol.180.10.6798

147. Guan Y, Pazgier M, Sajadi MM, Kamin-Lewis R, Al-Darmarki S, Flinko R, et al. Diverse specificity and effector function among human antibodies to HIV-1 envelope glycoprotein epitopes exposed by CD4 binding. Proc Natl Acad Sci U S A (2013) 110(1):E69-78. doi:10.1073/pnas.1217609110

148. Dey B, Berger EA. Towards an HIV cure based on targeted killing of infected cells: different approaches against acute versus chronic infection. Curr Opin HIV AIDS (2015) 10(3):207-13. doi:10.1097/COH.0000000000000151

149. Saxena A, Wu D. Advances in therapeutic Fc engineering - modulation of IgG-associated effector functions and serum half-life. Front Immunol (2016) 7:580. doi:10.3389/fimmu.2016.00580

150. Nimmerjahn F, Ravetch JV. Divergent immunoglobulin g subclass activity through selective Fc receptor binding. Science (2005) 310(5753):1510-2. doi:10.1126/science.1118948

151. Smith P, DiLillo DJ, Bournazos S, Li F, Ravetch JV. Mouse model recapitulating human Fcgamma receptor structural and functional diversity. Proc Natl Acad Sci U S A (2012) 109(16):6181-6. doi:10.1073/pnas.1203954109

152. Nimmerjahn F, Ravetch JV. Fcgamma receptors as regulators of immune responses. Nat Rev Immunol (2008) 8(1):34-47. doi:10.1038/nri2206

153. Asmal M, Hellmann I, Liu W, Keele BF, Perelson AS, Bhattacharya T, et al. A signature in HIV-1 envelope leader peptide associated with transition from acute to chronic infection impacts envelope processing and infectivity. PLoS One (2011) 6(8):e23673. doi:10.1371/journal.pone.0023673

154. Denton PW, Long JM, Wietgrefe SW, Sykes C, Spagnuolo RA, Snyder OD, et al. Targeted cytotoxic therapy kills persisting HIV infected cells during ART. PLoS Pathog (2014) 10(1):e1003872. doi:10.1371/journal.ppat. 1003872

155. Pincus SH, Song K, Maresh GA, Hamer DH, Dimitrov DS, Chen W, et al. Identification of human anti-HIV gp160 monoclonal antibodies that make effective immunotoxins. J Virol (2017) 91(3). doi:10.1128/JVI. 01955-16

156. May RD, Finkelman FD, Wheeler HT, Uhr JW, Vitetta ES. Evaluation of ricin A chain-containing immunotoxins directed against different epitopes on the delta-chain of cell surface-associated IgD on murine B cells. J Immunol (1990) 144(9):3637-42.

157. Pincus SH, McClure J. Soluble CD4 enhances the efficacy of immunotoxins directed against gp41 of the human immunodeficiency virus. Proc Natl Acad Sci U S A (1993) 90(1):332-6. doi:10.1073/pnas.90.1.332

158. Pincus SH, Song K, Maresh GA, Frank A, Worthylake D, Chung HK, et al. Design and in vivo characterization of immunoconjugates targeting HIV gp160. J Virol (2017) 91(3). doi:10.1128/JVI.01360-16

159. Mazor R, Onda M, Pastan I. Immunogenicity of therapeutic recombinant immunotoxins. Immunol Rev (2016) 270(1):152-64. doi:10.1111/ imr. 12390

160. Alvarez RA, Barria MI, Chen BK. Unique features of HIV-1 spread through T cell virological synapses. PLoS Pathog (2014) 10(12):e1004513. doi:10.1371/ journal.ppat.1004513

161. Parsons MS, et al. Partial efficacy of a broadly neutralizing antibody against cell-associated SHIV infection. Sci Transl Med (2017) 9(402). doi:10.1126/ scitranslmed.aaf1483

162. Milligan C, Overbaugh J. The role of cell-associated virus in mother-to-child HIV transmission. J Infect Dis (2014) 210(Suppl 3):S631-40. doi:10.1093/ infdis/jiu344

163. Jung A, Maier R, Vartanian JP, Bocharov G, Jung V, Fischer U, et al. Recombination: multiply infected spleen cells in HIV patients. Nature (2002) 418(6894):144. doi:10.1038/418144a

164. Zhong P, Agosto LM, Ilinskaya A, Dorjbal B, Truong R, Derse D, et al. Cell-to-cell transmission can overcome multiple donor and target cell barriers imposed on cell-free HIV. PLoS One (2013) 8(1):e53138. doi:10.1371/ journal.pone. 0053138

165. Russell RA, Martin N, Mitar I, Jones E, Sattentau QJ. Multiple proviral integration events after virological synapse-mediated HIV-1 spread. Virology (2013) 443(1):143-9. doi:10.1016/j.virol.2013.05.005
166. Reh L, Magnus C, Schanz M, Weber J, Uhr T, Rusert P, et al. Capacity of broadly neutralizing antibodies to inhibit HIV-1 cell-cell transmission is strain- and epitope-dependent. PLoS Pathog (2015) 11(7):e1004966. doi:10.1371/journal.ppat.1004966

167. Dale BM, McNerney GP, Thompson DL, Hubner W, de Los Reyes K, Chuang FY, et al. Cell-to-cell transfer of HIV-1 via virological synapses leads to endosomal virion maturation that activates viral membrane fusion. Cell Host Microbe (2011) 10(6):551-62. doi:10.1016/j.chom.2011.10.015

168. Margolis DM, Koup RA, Ferrari G. HIV antibodies for treatment of HIV infection. Immunol Rev (2017) 275(1):313-23. doi:10.1111/imr.12506

169. Gandhi RT, Bosch RJ, Aga E, Albrecht M, Demeter LM, Dykes C, et al. No evidence for decay of the latent reservoir in HIV-1-infected patients receiving intensive enfuvirtide-containing antiretroviral therapy. JInfect Dis (2010) 201(2):293-6. doi:10.1086/649569

170. McMahon D, Jones J, Wiegand A, Gange SJ, Kearney M, Palmer S, et al. Short-course raltegravir intensification does not reduce persistent low-level viremia in patients with HIV-1 suppression during receipt of combination antiretroviral therapy. Clin Infect Dis (2010) 50(6):912-9. doi:10.1086/650749

171. Dinoso JB, Kim SY, Wiegand AM, Palmer SE, Gange SJ, Cranmer L, et al. Treatment intensification does not reduce residual HIV-1 viremia in patients on highly active antiretroviral therapy. Proc Natl Acad Sci U S A (2009) 106(23):9403-8. doi:10.1073/pnas.0903107106

172. Anderson JA, Archin NM, Ince W, Parker D, Wiegand A, Coffin JM, et al. Clonal sequences recovered from plasma from patients with residual HIV-1 viremia and on intensified antiretroviral therapy are identical to replicating viral RNAs recovered from circulating resting CD4+ T cells. J Virol (2011) 85(10):5220-3. doi:10.1128/JVI.00284-11

173. Lorenzo-Redondo R, Fryer HR, Bedford T, Kim EY, Archer J, Pond SLK, et al. Persistent HIV-1 replication maintains the tissue reservoir during therapy. Nature (2016) 530(7588):51-6. doi:10.1038/nature16933

174. Vallejo A, Gutierrez C, Hernandez-Novoa B, Diaz L, Madrid N, AbadFernandez M, et al. The effect of intensification with raltegravir on the HIV-1 reservoir of latently infected memory CD4 T cells in suppressed patients. AIDS (2012) 26(15):1885-94. doi:10.1097/QAD.0b013e3283584521

175. Chun TW, Murray D, Justement JS, Blazkova J, Hallahan CW, Fankuchen O, et al. Broadly neutralizing antibodies suppress HIV in the persistent viral reservoir. Proc Natl Acad Sci U S A (2014) 111(36):13151-6. doi:10.1073/ pnas. 1414148111

176. Josefsson L, von Stockenstrom S, Faria NR, Sinclair E, Bacchetti P, Killian M, et al. The HIV-1 reservoir in eight patients on long-term suppressive antiretroviral therapy is stable with few genetic changes over time. Proc Natl Acad Sci U S A (2013) 110(51):E4987-96. doi:10.1073/pnas. 1308313110

177. Kearney MF, Spindler J, Shao W, Yu S, Anderson EM, O'Shea A, et al. Lack of detectable HIV-1 molecular evolution during suppressive antiretroviral therapy. PLoS Pathog (2014) 10(3):e1004010. doi:10.1371/journal. ppat. 1004010

178. Hocqueloux L, Prazuck T, Avettand-Fenoel V, Lafeuillade A, Cardon B, Viard JP, et al. Long-term immunovirologic control following antiretroviral therapy interruption in patients treated at the time of primary HIV-1 infection. AIDS (2010) 24(10):1598-601. doi:10.1097/QAD.0b013e32833b61ba

179. Sáez-Cirión A, Bacchus C, Hocqueloux L, Avettand-Fenoel V, Girault I, Lecuroux C, et al. Post-treatment HIV-1 controllers with a long-term virological remission after the interruption of early initiated antiretroviral therapy ANRS VISCONTI Study. PLoS Pathog (2013) 9(3):e1003211. doi:10.1371/ journal.ppat.1003211

180. Persaud D, Gay H, Ziemniak C, Chen YH, Piatak M Jr, Chun TW, et al. Absence of detectable HIV-1 viremia after treatment cessation in an infant. N Engl J Med (2013) 369(19):1828-35. doi:10.1056/NEJMoa1302976

181. Chun TW, Carruth L, Finzi D, Shen X, DiGiuseppe JA, Taylor H, et al. Quantification of latent tissue reservoirs and total body viral load in HIV-1 infection. Nature (1997) 387(6629):183-8. doi:10.1038/387183a0

182. Hill AL, Rosenbloom DI, Fu F, Nowak MA, Siliciano RF. Predicting the outcomes of treatment to eradicate the latent reservoir for HIV-1. Proc Natl Acad Sci U S A (2014) 111(37):13475-80. doi:10.1073/pnas. 1406663111

183. Wong JK, Yukl SA. Tissue reservoirs of HIV. Curr Opin HIV AIDS (2016) 11(4):362-70. doi:10.1097/COH.0000000000000293 
184. Lee GQ, Lichterfeld M. Diversity of HIV-1 reservoirs in CD4+ T-cell subpopulations. Curr Opin HIV AIDS (2016) 11(4):383-7. doi:10.1097/ COH.0000000000000281

185. Fletcher CV, Staskus K, Wietgrefe SW, Rothenberger M, Reilly C, Chipman JG, et al. Persistent HIV-1 replication is associated with lower antiretroviral drug concentrations in lymphatic tissues. Proc Natl Acad Sci U S A (2014) 111(6):2307-12. doi:10.1073/pnas.1318249111

186. Gray LR, Brew BJ, Churchill MJ. Strategies to target HIV-1 in the central nervous system. Curr Opin HIV AIDS (2016) 11(4):371-5. doi:10.1097/ COH.0000000000000278

187. Sacha JB, Ndhlovu LC. Strategies to target non-T-cell HIV reservoirs. Curr Opin HIV AIDS (2016) 11(4):376-82. doi:10.1097/COH.0000000000000283

188. DeMaster LK, Liu X, VanBelzen DJ, Trinité B, Zheng L, Agosto LM, et al. A subset of CD4/CD8 double-negative T cells expresses HIV proteins in patients on antiretroviral therapy. J Virol (2015) 90(5):2165-79. doi:10.1128/ JVI.01913-15

189. Koppensteiner H, Brack-Werner R, Schindler M. Macrophages and their relevance in human immunodeficiency virus type I infection. Retrovirology (2012) 9:82. doi:10.1186/1742-4690-9-82

190. Cribbs SK, Lennox J, Caliendo AM, Brown LA, Guidot DM. Healthy HIV-1-infected individuals on highly active antiretroviral therapy harbor HIV-1 in their alveolar macrophages. AIDS Res Hum Retroviruses (2015) 31(1):64-70. doi:10.1089/AID.2014.0133

191. Heesters BA, Lindqvist M, Vagefi PA, Scully EP, Schildberg FA, Altfeld M, et al. Follicular dendritic cells retain infectious HIV in cycling endosomes. PLoS Pathog (2015) 11(12):e1005285. doi:10.1371/journal.ppat. 1005285

192. Smith BA, Gartner S, Liu Y, Perelson AS, Stilianakis NI, Keele BF, et al. Persistence of infectious HIV on follicular dendritic cells. J Immunol (2001) 166(1):690-6. doi:10.4049/jimmunol.166.1.690

193. Euler Z, Alter G. Exploring the potential of monoclonal antibody therapeutics for HIV-1 eradication. AIDS Res Hum Retroviruses (2015) 31(1): 13-24. doi:10.1089/AID.2014.0235

194. Ruxrungtham K, Sirivichayakul S, Buranapraditkun S, Krause W. Alemtuzumab-induced elimination of HIV-1-infected immune cells. J Virus Erad (2016) 2(1):12-8.

195. Rasmussen TA, McMahon J, Chang JJ, Symons J, Roche M, Dantanarayana A, et al. Impact of alemtuzumab on HIV persistence in an HIV-infected individual on antiretroviral therapy with Sezary syndrome. AIDS (2017) 31(13):1839-45. doi:10.1097/QAD.0000000000001540

196. Descours B, Petitjean G, López-Zaragoza JL, Bruel T, Raffel R, Psomas C, et al. CD32a is a marker of a CD4 T-cell HIV reservoir harbouring replication-competent proviruses. Nature (2017) 543(7646):564-7. doi:10.1038/ nature 21710

197. Marsden MD, Zack JA. Neutralizing the HIV reservoir. Cell (2014) 158(5):971-2. doi:10.1016/j.cell.2014.08.010

198. Rinaldo C, Huang XL, Fan ZF, Ding M, Beltz L, Logar A, et al. High levels of anti-human immunodeficiency virus type 1 (HIV-1) memory cytotoxic T-lymphocyte activity and low viral load are associated with lack of disease in HIV-1-infected long-term nonprogressors. J Virol (1995) 69(9): 5838-42.

199. Klein MR, van Baalen CA, Holwerda AM, Kerkhof Garde SR, Bende RJ, Keet IP, et al. Kinetics of Gag-specific cytotoxic T lymphocyte responses during the clinical course of HIV-1 infection: a longitudinal analysis of rapid progressors and long-term asymptomatics. J Exp Med (1995) 181(4): 1365-72. doi:10.1084/jem.181.4.1365

200. Pinto LA, Sullivan J, Berzofsky JA, Clerici M, Kessler HA, Landay AL, et al. ENV-specific cytotoxic T lymphocyte responses in HIV seronegative health care workers occupationally exposed to HIV-contaminated body fluids. J Clin Invest (1995) 96(2):867-76. doi:10.1172/JCI118133

201. Sung JA, Pickeral J, Liu L, Stanfield-Oakley SA, Lam CY, Garrido C, et al. Dual-affinity re-targeting proteins direct T cell-mediated cytolysis of latently HIV-infected cells. JClin Invest (2015) 125(11):4077-90. doi:10.1172/ JCI82314

202. Pegu A, Asokan M, Wu L, Wang K, Hataye J, Casazza JP, et al. Activation and lysis of human CD4 cells latently infected with HIV-1. Nat Commun (2015) 6:8447. doi:10.1038/ncomms 9447

203. Scholler J, Brady TL, Binder-Scholl G, Hwang WT, Plesa G, Hege KM, et al. Decade-long safety and function of retroviral-modified chimeric antigen receptor T cells. Sci Transl Med (2012) 4(132):132ra53. doi:10.1126/ scitranslmed. 3003761

204. Zhen A, Kamata M, Rezek V, Rick J, Levin B, Kasparian S, et al. HIVspecific immunity derived from chimeric antigen receptor-engineered stem cells. Mol Ther (2015) 23(8):1358-67. doi:10.1038/mt.2015.102

205. Carrillo MA, Zhen A, Zack JA, Kitchen SG. New approaches for the enhancement of chimeric antigen receptors for the treatment of HIV. Transl Res (2017). doi:10.1016/j.trsl.2017.07.002

206. Egelhofer M, Brandenburg G, Martinius H, Schult-Dietrich P, Melikyan G, Kunert R, et al. Inhibition of human immunodeficiency virus type 1 entry in cells expressing gp41-derived peptides. J Virol (2004) 78(2):568-75. doi:10.1128/JVI.78.2.568-575.2004

207. Younan PM, Polacino P, Kowalski JP, Peterson CW, Maurice NJ, Williams NP, et al. Positive selection of mC46-expressing CD4+ $\mathrm{T}$ cells and maintenance of virus specific immunity in a primate AIDS model. Blood (2013) 122(2):179-87. doi:10.1182/blood-2013-01-482224

208. Holt N, Wang J, Kim K, Friedman G, Wang X, Taupin V, et al. Human hematopoietic stem/progenitor cells modified by zinc-finger nucleases targeted to CCR5 control HIV-1 in vivo. Nat Biotechnol (2010) 28(8): 839-47. doi:10.1038/nbt.1663

209. Shimizu S, Ringpis GE, Marsden MD, Cortado RV, Wilhalme HM, Elashoff D, et al. RNAi-mediated CCR5 knockdown provides HIV-1 resistance to memory T cells in humanized BLT mice. Mol Ther Nucleic Acids (2015) 4:e227. doi:10.1038/mtna.2015.3

210. Li C, Guan X, Du T, Jin W, Wu B, Liu Y, et al. Inhibition of HIV-1 infection of primary CD4+ T-cells by gene editing of CCR5 using adenovirusdelivered CRISPR/Cas9. J Gen Virol (2015) 96(8):2381-93. doi:10.1099/ vir. 0.000139

211. Kang H, Minder P, Park MA, Mesquitta WT, Torbett BE, Slukvin II. CCR5 disruption in induced pluripotent stem cells using CRISPR/Cas9 provides selective resistance of immune cells to CCR5-tropic HIV-1 virus. Mol Ther Nucleic Acids (2015) 4:e268. doi:10.1038/mtna.2015.42

212. Dotti G, Gottschalk S, Savoldo B, Brenner MK. Design and development of therapies using chimeric antigen receptor-expressing $\mathrm{T}$ cells. Immunol Rev (2014) 257(1):107-26. doi:10.1111/imr.12131

213. Kalos M, Levine BL, Porter DL, Katz S, Grupp SA, Bagg A, et al. T cells with chimeric antigen receptors have potent antitumor effects and can establish memory in patients with advanced leukemia. Sci Transl Med (2011) 3(95):95ra73. doi:10.1126/scitranslmed.3002842

214. Grupp SA, Kalos M, Barrett D, Aplenc R, Porter DL, Rheingold SR, et al. Chimeric antigen receptor-modified $\mathrm{T}$ cells for acute lymphoid leukemia. N Engl J Med (2013) 368(16):1509-18. doi:10.1056/NEJMoa1215134

215. Cavazzana-Calvo M, Fischer A, Hacein-Bey-Abina S, Aiuti A. Gene therapy for primary immunodeficiencies: part 1. Curr Opin Immunol (2012) 24(5):580-4. doi:10.1016/j.coi.2012.08.008

216. Morgan RA, Yang JC, Kitano M, Dudley ME, Laurencot CM, Rosenberg SA. Case report of a serious adverse event following the administration of $\mathrm{T}$ cells transduced with a chimeric antigen receptor recognizing ERBB2. Mol Ther (2010) 18(4):843-51. doi:10.1038/mt.2010.24

217. Lienert F, Lohmueller JJ, Garg A, Silver PA. Synthetic biology in mammalian cells: next generation research tools and therapeutics. Nat Rev Mol Cell Biol (2014) 15(2):95-107. doi:10.1038/nrm3738

218. de Witte MA, Jorritsma A, Swart E, Straathof KC, de Punder K, Haanen JB, et al. An inducible caspase 9 safety switch for T-cell therapy. Blood (2005) 105(11):4247-54. doi:10.1182/blood-2004-11-4564

219. Di Stasi A, Tey SK, Dotti G, Fujita Y, Kennedy-Nasser A, Martinez C, et al. Inducible apoptosis as a safety switch for adoptive cell therapy. $N$ Engl J Med (2011) 365(18):1673-83. doi:10.1056/NEJMoa1106152

220. Wei P, Wong WW, Park JS, Corcoran EE, Peisajovich SG, Onuffer JJ, et al. Bacterial virulence proteins as tools to rewire kinase pathways in yeast and immune cells. Nature (2012) 488(7411):384-8. doi:10.1038/ nature 11259

221. Roybal KT, Williams JZ, Morsut L, Rupp LJ, Kolinko I, Choe JH, et al. Engineering T cells with customized therapeutic response programs using synthetic notch receptors. Cell (2016) 167(2):419-32.e16. doi:10.1016/j. cell.2016.09.011

222. Roybal KT, Rupp LJ, Morsut L, Walker WJ, McNally KA, Park JS, et al. Precision tumor recognition by $\mathrm{T}$ cells with combinatorial antigensensing circuits. Cell (2016) 164(4):770-9. doi:10.1016/j.cell.2016.01.011 
223. Wilkie S, van Schalkwyk MC, Hobbs S, Davies DM, van der Stegen SJ, Pereira AC, et al. Dual targeting of ErbB2 and MUC1 in breast cancer using chimeric antigen receptors engineered to provide complementary signaling. J Clin Immunol (2012) 32(5):1059-70. doi:10.1007/s10875-0129689-9

224. Lanitis E, Poussin M, Klattenhoff AW, Song D, Sandaltzopoulos R, June $\mathrm{CH}$, et al. Chimeric antigen receptor T Cells with dissociated signaling domains exhibit focused antitumor activity with reduced potential for toxicity in vivo. Cancer Immunol Res (2013) 1(1):43-53. doi:10.1158/23266066.CIR-13-0008

225. Kloss CC, Condomines M, Cartellieri M, Bachmann M, Sadelain M. Combinatorial antigen recognition with balanced signaling promotes selective tumor eradication by engineered T cells. Nat Biotechnol (2013) 31(1):71-5. doi:10.1038/nbt.2459

226. Fukazawa Y, Lum R, Okoye AA, Park H, Matsuda K, Bae JY, et al. B cell follicle sanctuary permits persistent productive simian immunodeficiency virus infection in elite controllers. Nat Med (2015) 21(2):132-9. doi:10.1038/ nm.3781

227. Kaminski R, Chen Y, Fischer T, Tedaldi E, Napoli A, Zhang Y, et al. Elimination of HIV-1 genomes from human T-lymphoid cells by CRISPR/ Cas9 gene editing. Sci Rep (2016) 6:22555. doi:10.1038/srep28213

Conflict of Interest Statement: The authors declare that the research was conducted in the absence of any commercial or financial relationships that could be construed as a potential conflict of interest.

Copyright (C) 2017 Hua and Ackerman. This is an open-access article distributed under the terms of the Creative Commons Attribution License (CC BY). The use, distribution or reproduction in other forums is permitted, provided the original author(s) or licensor are credited and that the original publication in this journal is cited, in accordance with accepted academic practice. No use, distribution or reproduction is permitted which does not comply with these terms. 